
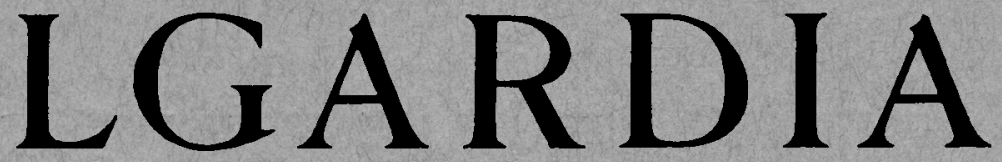

A Journal of Agricultural Science Published by the California Agricultural Experiment Station

GROWTH AND BULBING OF GARLIC (ALIIUM SATIVUM L.) IN RESPONSE TO STORAGE TEMPERATURE OF PLANTING STOCKS, DAY LENGTH, AND PLANTING DATE LOUIS K. MANN and P. A. MINGES 
Garlic is a condiment crop of limited use and fairly constant market demand. About half of the garlic consumed in the United States is grown domestically, and almost all of this in California where some 2,000 acres are grown each year. Although a minor crop, it has been an important source of income in local areas for many years.

Garlic growing is strictly seasonal; except for small differences among kinds of garlic and among growing areas, the cloves are planted in the winter months, start growth almost immediately, and form mature plants in late spring or summer. Despite this strong seasonal response, little has been known of the environmental factors controlling the pattern of growth. The present paper discusses field and greenhouse experiments which show that bulb formation and plant maturity are controlled primarily by the temperature to which plants are exposed, both before and after planting in the field, and by the changing length of day during the spring growing period. These factors are considered as they relate to cultural practices and to the quality of the crop. 


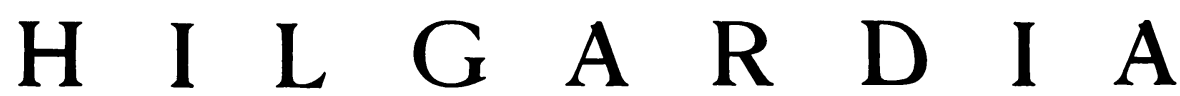

A Journal of Agricultural Science Published by

the California Agricultural Experiment Station

VOL. 27

AUGUST, 1958

No. 15

\section{GROWTH AND BULBING OF GARLIC (ALLIUM SATIVUM L.) IN RESPONSE TO STORAGE TEMPERATURE OF PLANTING STOCKS, DAY LENGTH, AND PLANTING DATE ${ }^{1}$}

\author{
LOUIS K. MANN ${ }^{3}$ and P. A. MINGES ${ }^{3}$
}

\section{INTRODUCTION}

ENVIRONMENTAL FACTORS controlling bulbing of garlic have been discussed in a previous paper by Mann (1952) ${ }^{4}$ who reported that bulbing was induced by long days and that bulbs formed more quickly under warm than under cool temperatures. Storage of bulbs at low temperatures $\left(0^{\circ}\right.$ to $\left.5^{\circ} \mathrm{C}\right)$ before planting hastened subsequent bulbing and maturity as compared with storage at warmer temperatures $\left(10^{\circ}\right.$ to $\left.15^{\circ} \mathrm{C}\right)$. The response to these preplanting storage temperatures varied with the growing conditions, being greatest for greenhouse-grown plants which received no further exposure to low temperature after they were planted. Preplanting storage temperatures were also reported to affect the rate of clove sprouting, and this aspect of the problem was further studied by Mann and Lewis (1956). The present paper is a continuation of these physiological studies.

Greenhouse studies have clarified the role of low temperature as a requirement for subsequent bulb formation, and this information has been used to interpret the results of field tests with bulbs stored at a series of temperatures and set out at two or more planting dates. Since seedstalks did not appear consistently in any of the tests reported here, the physiology of bolting is not discussed.

The garlic used in the experiments described in this paper was the California Late garlic (see Mann and Little, 1957, for description), which is the major cultivar (cultivated variety) in California. Material for these tests was derived from several single bulb selections from farmers' fields. These bulbs were propagated as clonal lines for several years at Davis and were free from white rot (Sclerotium cepivorum) and stem and bulb nematode (Ditylenchus dipsaci). Among these clonal lines, designated by arbitrary numbers in table 1 , there were small differences of vigor and habit, but their reactions under experimental conditions were similar.

Bulbs were broken into cloves immediately before planting. For field

${ }^{1}$ Received for publication October 25, 1957.

${ }^{2}$ Associate Professor of Vegetable Crops and Associate Olericulturist in the Experiment Station, Davis.

${ }^{3}$ Professor of Vegetable Crops, Cornell University, Ithaca, New York.

"See "Literature Cited" for citations referred to in the text by author and date. 
TABLE 1

EXPERIMENTS ON GARLIC USING CONTROLLED STORAGE OF PLANTING STOCK, PLANTING DATE, AND DAY LENGTH

\begin{tabular}{|c|c|c|c|c|c|}
\hline $\begin{array}{c}\text { Test } \\
\text { number }\end{array}$ & $\begin{array}{c}\text { Field or } \\
\text { greenhouse }\end{array}$ & $\begin{array}{l}\text { Location } \\
\text { in state }\end{array}$ & Treatments & $\begin{array}{c}\text { Clonal lines } \\
\text { used }\end{array}$ & $\begin{array}{l}\text { Inclusive dates } \\
\text { of test }\end{array}$ \\
\hline 1 & GH & Davis, Yolo Co. & $\begin{array}{l}3 \text { storage temperatures } \\
3 \text { planting dates } \\
\text { Natural day length }\end{array}$ & $7-6$ & $\begin{array}{l}\text { Aug. } 8,1952- \\
\text { Oct. } 5,1953\end{array}$ \\
\hline 2 & GH & Davis, Yolo Co. & $\begin{array}{l}2 \text { storage temperatures } \\
3 \text { planting dates } \\
\text { Natural day length }\end{array}$ & $4-10$ & $\begin{array}{l}\text { Oct. } 5,1953- \\
\text { Sept. 15, } 1954\end{array}$ \\
\hline 3 & GH & Davis, Yolo Co. & $\begin{array}{l}5 \text { storage temperatures } \\
1 \text { planting date } \\
\text { Controlled day length }\end{array}$ & $4-10$ & $\begin{array}{l}\text { Sept. 4, 1954- } \\
\text { May 10, } 1955\end{array}$ \\
\hline 4 & $\mathrm{~F}$ & Davis, Yolo Co. & $\begin{array}{l}6 \text { storage temperatures } \\
1 \text { planting date }\end{array}$ & $4-10$ & $\begin{array}{l}\text { Aug. 26, 1952- } \\
\text { Sept. 5, } 1953\end{array}$ \\
\hline 5 & F & Davis, Yolo Co. & $\begin{array}{l}5 \text { storage temperatures } \\
7 \text { planting dates }\end{array}$ & $7-4$ & $\begin{array}{l}\text { Aug. } 19,1952- \\
\text { Sept. } 5,1953\end{array}$ \\
\hline 6 & F & Davis, Yolo Co. & $\begin{array}{l}5 \text { storage temperatures } \\
6 \text { planting dates }\end{array}$ & $\begin{array}{l}1-4 \\
4-10 \\
7-1 \\
7-4\end{array}$ & $\begin{array}{l}\text { Aug. 20, 1953- } \\
\text { Sept. 22, } 1954\end{array}$ \\
\hline 7 & F & $\begin{array}{l}\text { Meloland Sta., } \\
\text { Imperial Co. }\end{array}$ & $\begin{array}{l}5 \text { storage temperatures } \\
5 \text { planting dates }\end{array}$ & $\begin{array}{l}1-4 \\
7-1\end{array}$ & $\begin{array}{l}\text { Aug. 20, 1953- } \\
\text { July } 16,1954\end{array}$ \\
\hline 8 & F & $\begin{array}{l}\text { Tulelake Sta., } \\
\text { Siskiyou Co. }\end{array}$ & $\begin{array}{l}5 \text { storage temperatures } \\
2 \text { planting dates }\end{array}$ & $\begin{array}{l}1-4 \\
7-4\end{array}$ & $\begin{array}{l}\text { Aug. 20, 1953- } \\
\text { Oct. 20,1954 }\end{array}$ \\
\hline 9 & F & $\begin{array}{l}\text { San Juan Bautista, } \\
\text { San Benito Co. }\end{array}$ & $\begin{array}{l}5 \text { storage temperatures } \\
3 \text { planting dates }\end{array}$ & $\begin{array}{l}7-4 \\
4-10\end{array}$ & $\begin{array}{l}\text { Aug. 20, 1953- } \\
\text { Aug. 24, 1954 }\end{array}$ \\
\hline 10 & F & $\begin{array}{l}\text { Gilroy, Santa } \\
\text { Clara Co. }\end{array}$ & $\begin{array}{l}4 \text { storage temperatures } \\
3 \text { planting dates }\end{array}$ & $\begin{array}{l}6-4 \\
3-8\end{array}$ & $\begin{array}{l}\text { Aug. 20, 1953- } \\
\text { Aug. 2, 1954 }\end{array}$ \\
\hline 11 & F & Davis, Yolo Co. & $\begin{array}{l}2 \text { storage temperatures } \\
4 \text { planting dates }\end{array}$ & $\begin{array}{l}7-4 \\
7-6\end{array}$ & $\begin{array}{r}\text { Aug. } 20,1953- \\
\text { Aug. 2, } 1954\end{array}$ \\
\hline
\end{tabular}

tests, the cloves were planted by hand on two-row beds, 2 to 3 inches apart in the row. When planted in dry soil, they were irrigated the same day. The usual cultural methods, as described by Mann and Little (1957), were followed. Greenhouse cultural methods are described individually under each test.

Bulbs stored at controlled temperatures before planting were placed in paper bags in refrigerated or heated rooms where temperatures varied less than $\pm 0.5^{\circ} \mathrm{C}$ from those indicated. Humidity was not controlled in the storage rooms.

The degree of bulbing of garlic plants is estimated by measuring the bulb and neck diameters, and expressing this as a ratio-neck diameter/bulb diameter. The neck (false stem) is measured about 1 inch above the bulb. This ratio appears to be a reasonable measure of bulb formation and is 
largely independent of plant size. Its numerical value always lies below 1.0even young plants are slightly swollen at the base--but must be below about 0.5 to indicate definite bulb formation (Mann, 1952).

Table 1 gives basic information about the tests described in this paper. Tests 1 to 3 will be described in more detail under "Greenhouse Tests," and tests 4 to 11 under "Field Tests."

\section{GREENHOUSE TESTS: RESPONSE OF GARLIC TO STORAGE TEMPERATURE OF PLANTING STOCK AND TO DAY LENGTH}

\section{Materials and Methods}

Test 1 bulbs were grown in the field at Davis, harvested July 29 and 30, 1952 , and held in slatted crates, in the shade, on the north side of a large building. On August 8, three lots of 33 bulbs each were placed in each of three controlled-temperature rooms held at $0^{\circ}, 5^{\circ}$, and $10^{\circ} \mathrm{C}$. On September 8, 33 cloves from each of the three temperatures were planted in a soil bench. Similar plantings were made on October 6 and November 3. This experiment continued through the winter and was terminated the following October. The plants were exposed to natural day lengths, and, during the summer, the greenhouse was cooled so that the day temperature did not exceed $27^{\circ} \mathrm{C}$ for more than three hours a day through the hot days of June, July, and August.

Test 2 garlic was planted in the field at Davis on February 20, 1953, and dug on August 10. It was cured about one week in the field, topped, placed in a well-ventilated room, and then stored and planted according to the following schedule:

$\begin{array}{cccc}\text { INTO STORAGE } & \text { WEEKS AT } 5^{\circ} \mathrm{C} & \text { WEEKS AT } 20^{\circ} \mathrm{C} & \text { DATE PLANTED } \\ \text { Oct. 5, 1953 } & 12 & 0 & \text { Jan. 5, } 1954 \\ \text { Oct. 5, } 1953 & 0 & 12 & \text { Jan. } 5,1954 \\ \text { Oct. 5, } 1953 & 18 & 0 & \text { Feb. 16, 1954 } \\ \text { Oct. 5, } 1953 & 12 & 6 & \text { Feb. 16, } 1954 \\ \text { Oct. 5, } 1953 & 20 & 0 & \text { Mar. 2, 1954 } \\ \text { Oct. 5, } 1953 & 12 & 8 & \text { Mar. 2, 1954 }\end{array}$

The cloves were then planted in a soil bench in a greenhouse held at $18^{\circ} \mathrm{C}$ at night and at $24^{\circ} \mathrm{C}$ during the day. The day temperatures did not exceed $27^{\circ} \mathrm{C}$ for more than three hours a day during the hot days of June through August. The plants were exposed to natural day lengths.

Test 3 garlic was grown at Davis and dug on July 19, 1954. The harvested bulbs were dusted with sulfur, and fumigated later with 2.5 pounds of methyl bromide per 1,000 cubic feet of space, at $27^{\circ} \mathrm{C}$ for two hours. These treatments were applied to control the mite Acera tulipae Kiefer. The bulbs were kept in a well-ventilated, unheated room until September 4 , when they were placed in paper bags in storage rooms held at $0^{\circ}, 5^{\circ}, 10^{\circ}, 15^{\circ}$, and $20^{\circ} \mathrm{C}$. Humidity was not controlled in the storage rooms. On December 24, after 12 weeks of storage, the bulbs were removed. On December 27 they were 
planted, one clove to a 5 -inch pot of soil, in a greenhouse held at $21^{\circ} \mathrm{C}$ day and night. By January 22 all cloves had sprouted, and on January 27 half of the lots were placed under short days (10 hours) and half under long days (16.5 hours) where they remained until the end of the experiment. There were 12 pots from each of the five storage temperatures under each of the day lengths (120 pots in all).

\section{Results of Greenhouse Tests}

Test 1. Although storage of garlic bulbs at low temperatures prior to planting has been observed to hasten bulbing and maturity (Mann, 1952), the results of test 1 first suggested that a period of exposure to low temperature is required for subsequent bulbing.

As noted above, bulbs stored for approximately one, two, and three months at each of three temperatures- $0^{\circ}, 5^{\circ}$, and $10^{\circ} \mathrm{C}$-were planted in a soil bench in a greenhouse held at $18^{\circ} \mathrm{C}$ night and $21^{\circ} \mathrm{C}$ day temperatures.

The data on bulbing and plant maturity for the $0^{\circ}$ and $5^{\circ} \mathrm{C}$ storage lots are briefly as follows: plants from bulbs stored for three months before planting matured most quickly, even though planted later than those stored for one and two months; for each planting date, the plants from bulbs stored at $5^{\circ} \mathrm{C}$ matured a few days sooner than did those from the $0^{\circ} \mathrm{C}$ storage.

Plants from cloves stored at $5^{\circ} \mathrm{C}$ before planting matured as follows: three months' storage—early June; two months' storage-early August; one month's storage-early October (partial bulbing only).

Plants from cloves stored at $10^{\circ} \mathrm{C}$ matured irregularly-even the lot which had been in storage for three months. On October 2, all the plants from the $10^{\circ} \mathrm{C}$ storage treatments were examined for bulbs. Of those from cloves stored for three months, and which were partly mature in early August, eight plants remained without bulbs. From cloves stored two months there were 26 nonbulbing plants, and from cloves stored one month, 21 nonbulbing plants. The number of plants without bulbs in the latter group was reduced by the bulbing of three to four rows of plants adjacent to the north glass of the greenhouse. All these plants bulbed, regardless of prior treatment, presumably because of the lower air and soil temperature in that location.

Most of the nonbulbing plants were saved for a further experiment, but three were dissected to determine the total number of leaves formed. These three had 41 to 43 leaves each, counting the protective leaf of the clove as the first leaf and including the leaf primordia. Cloves or clove primordia were not present.

From this test it was concluded that rapid and complete bulbing of garlic planted in the autumn in an $18^{\circ}$ to $21^{\circ} \mathrm{C}$ greenhouse, under natural day lengths, was dependent on an adequate exposure to low temperature prior to planting.

Test 2. This test confirmed the results of test 1 . Garlic bulbs were stored at $5^{\circ}$ and $20^{\circ} \mathrm{C}$, and at two combinations of $5^{\circ}$ and $20^{\circ} \mathrm{C}$, before being planted in a greenhouse under natural day lengths. Bulbing was measured by determining the neck diameter/bulb diameter ratios as described under "Introduction," page 386. Ratios for six dates are given in table 2, each 
figure representing from 7 to 20 plants. Values below 0.50 indicate definite bulbing.

These data show that plants from planting stock stored at $20^{\circ} \mathrm{C}$ will not form bulbs in an $18^{\circ}$ to $24^{\circ} \mathrm{C}$ greenhouse under natural day lengths, but those from planting stock stored at $5^{\circ} \mathrm{C}$ form bulbs readily. Storage at $20^{\circ} \mathrm{C}$ following storage at $5^{\circ} \mathrm{C}$ counteracts, to some extent, the effect of the lowtemperature storage.

TABLE 2

BULBING OF GARLIC GROWN FROM BULBS STORED AT $5^{\circ}$ AND $20^{\circ} \mathrm{C}$, AND AT TWO COMBINATIONS OF $5^{\circ}$ A'ND $20^{\circ}$ C. PLANTS GROWN UNDER NATURAL DAY LENGTHS IN AN $18^{\circ} \mathrm{C}$ (NIGHT)$24^{\circ} \mathrm{C}$ (DAY) GREENHOUSE

(Test 2, Davis)

\begin{tabular}{|c|c|c|c|c|c|c|}
\hline \multirow{3}{*}{ Observation dates } & \multicolumn{6}{|c|}{$\begin{array}{l}\text { Neck diameter/bulb diameter ratio } \\
\text { (Values below about } 0.50 \text { indicate definite bulbing.) }\end{array}$} \\
\hline & \multicolumn{2}{|c|}{ Planted Jan. 5} & \multicolumn{2}{|c|}{ Planted Feb. 16} & \multicolumn{2}{|c|}{ Planted Mar. 2} \\
\hline & $\begin{array}{c}3 \mathrm{mo} . \\
\text { at } \\
5^{\circ} \mathrm{C}\end{array}$ & $\begin{array}{l}3 \mathrm{mo} . \\
\text { at } \\
20^{\circ} \mathrm{C}\end{array}$ & $\begin{array}{c}4.5 \mathrm{mo} \\
\text { at } \\
5^{\circ} \mathrm{C}\end{array}$ & $\left|\begin{array}{c}3 \mathrm{mo} \text { at } \\
5^{\circ} \mathrm{C}+1.5 \\
\text { mo. at } 20^{\circ} \mathrm{C}\end{array}\right|$ & $\begin{array}{c}5 \mathrm{mo} . \\
\text { at } \\
5^{\circ} \mathrm{C}\end{array}$ & $\mid \begin{array}{c}3 \mathrm{mo} \text { at } \\
5^{\circ} \mathrm{C}+2 \\
\text { mo. at } 20^{\circ} \mathrm{C}\end{array}$ \\
\hline May 26. & 0.22 & 0.66 & 0.31 & 0.60 & 0.37 & 0.61 \\
\hline June $15 .$. & 0.17 & 0.65 & 0.24 & 0.58 & 0.16 & 0.63 \\
\hline July 8. & mature & 0.61 & 0.24 & 0.48 & 0.16 & 0.51 \\
\hline July 28 . & $\ldots$ & 0.61 & 0.11 & 0.40 & 0.10 & 0.48 \\
\hline Aug. 19 & $\ldots$ & 0.57 & mature & 0.31 & mature & 0.40 \\
\hline Sept. 15 . & & 0.57 & 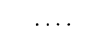 & 0.21 & $\ldots$ & 0.31 \\
\hline
\end{tabular}

Test 3. This test was designed to relate previous observations on day length and preplanting storage temperatures. Garlic cloves from bulbs stored at $0^{\circ}, 5^{\circ}, 10^{\circ}, 15^{\circ}$, and $20^{\circ} \mathrm{C}$ for 12 weeks were grown under 10 -hour and 16.5-hour day lengths.

As would be expected (Mann and Lewis, 1956), the cloves sprouted irregularly, those from the $5^{\circ}$ and $10^{\circ} \mathrm{C}$ storage sprouting first and producing, for a time, the largest tops. On February 18 all pots were fertilized, and it was noted that, in some lots, the food storage leaves had become depleted. Under the long-day treatment, for example, only one solid storage leaf remained among the 24 cloves previously stored at $5^{\circ}$ or $10^{\circ} \mathrm{C}$, while 25 were still firm among the 36 cloves previously stored at $0^{\circ}, 15^{\circ}$, or $20^{\circ} \mathrm{C}$. This depletion of storage leaves indicates the decreased rest and rapid subsequent growth following storage at $5^{\circ}$ and $10^{\circ} \mathrm{C}$.

To evaluate bulbing, neck and bulb diameters were measured and the bulbing ratio (neck diameter/bulb diameter) was plotted for each treatment on four dates (fig. 1).

Under long days the dates of maturity, as judged by falling and drying of tops, were recorded for each pot, and the average maturity date was calculated for each treatment. After drying, the bulbs were weighed (less tops and roots) and the cloves counted. These harvest data are recorded in table 3. 


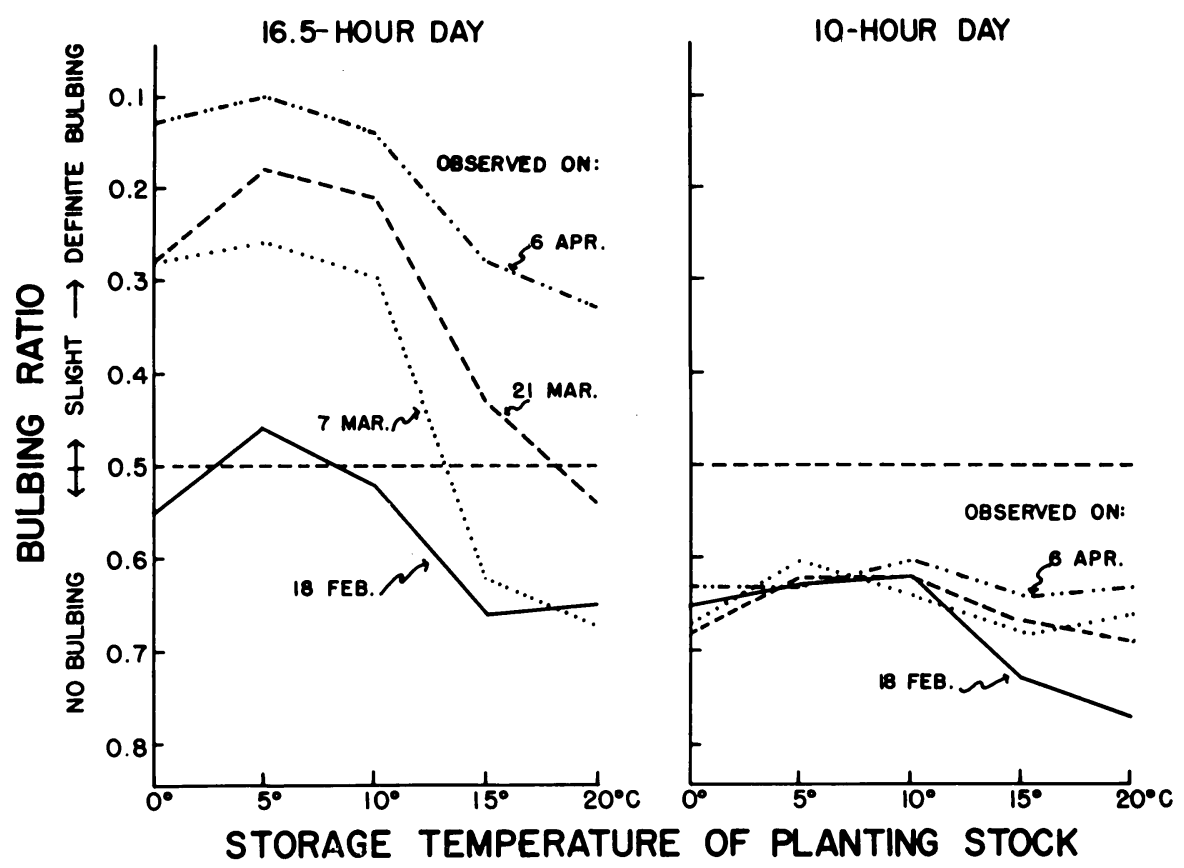

Fig. 1. Bulbing of garlic grown under long and short days from cloves stored for 12 weeks at five temperatures. Cloves planted December 27, placed under controlled day lengths January 27, and measured on four dates as indicated. Bulbing ratios (neck diameter/bulb diameter) below 0.50 indicate definite bulbing. Each point is the mean of 12 plants. (Test 3, Davis.)

Because the plants were placed under long day soon after sprouting, the bulbs were quite small.

Plants from bulbs previously stored at $0^{\circ}$ or $5^{\circ} \mathrm{C}$ frequently developed visible lateral sprouts, i.e., elongation of buds (cloves) from the outer leaf axils into green foliage leaves, sometimes to the extent that three separate false stems were present. On March 21, 10 of 24 plants from $0^{\circ} \mathrm{C}$ storage showed sprouts, as did 21 of 24 plants stored at $5^{\circ} \mathrm{C}$. This sprouting was independent of day length, and did not occur in bulbs stored above $5^{\circ} \mathrm{C}$ before planting.

The plants under short days showed no signs of bulbing by April 18, and by May 10, daytime greenhouse temperatures were becoming high and most of the plants were dying.

Under the conditions of the above test, garlic bulbed only under long days. Bulbing and maturity under long days were hastened by 12 weeks of preplanting storage at $5^{\circ}$ or $10^{\circ} \mathrm{C}$, as compared with $15^{\circ}$ or $20^{\circ} \mathrm{C}$, and the number of cloves formed per bulb decreased with increasing preplanting storage temperatures. Storage of bulbs at $0^{\circ}$ and $5^{\circ} \mathrm{C}$ favored the elongation of axial buds, giving rise to visible lateral shoots, or even to plants with several tops. 


\section{FIELD TESTS: RESPONSE OF GARLIC TO STORAGE TEMPERATURE OF PLANTING STOCK AND PLANTING DATE}

\section{Materials and Methods}

Basic data on the field tests are given in table 1. The details of the layout follow.

Test 4 garlic was grown at Davis, harvested July 29 to 30, 1952, and stored in slatted crates in the shade. On August 26, one unit of bulbs was placed at each of the temperatures, $0^{\circ}, 5^{\circ}, 10^{\circ}, 15^{\circ}, 20^{\circ}$, and $25^{\circ} \mathrm{C}$. On June 3 , 1953, after about nine months of storage, 10 cloves from each temperature were planted in the field at Davis. The test contained six units (6 storage temperatures $\mathrm{x} 1$ planting date $\mathrm{x} 1$ clonal line).

TABLE 3

HARVEST DATA FROM GARLIC PLANTED DECEMBER 27 AND GROWN CONTINUOUSLY, FROM JANUARY 27, UNDER 16.5-HOUR DAYS

(Test 3, Davis)

\begin{tabular}{|c|c|c|c|c|c|}
\hline \multirow{2}{*}{ Factor* } & \multicolumn{5}{|c|}{ Storaget temperature of planting stock } \\
\hline & $0^{\circ} \mathrm{C}$ & $5^{\circ} \mathrm{C}$ & $10^{\circ} \mathrm{C}$ & $15^{\circ} \mathrm{C}$ & $20^{\circ} \mathrm{C}$ \\
\hline $\begin{array}{l}\text { Mean maturity date..... } \\
\text { Mean bulb weight }(\mathrm{gm}) . \\
\text { Mean cloves per bulb... }\end{array}$ & $\begin{array}{c}\text { April } 7 \\
6.7 \\
9.4\end{array}$ & $\begin{array}{l}\text { April } 10 \\
8.7 \\
6.5\end{array}$ & $\begin{array}{c}\text { April } 17 \\
8.1 \\
3.2\end{array}$ & $\begin{array}{c}\text { May } 8 \\
8.3 \\
1.6\end{array}$ & $\begin{array}{l}\text { May } 16 \\
7.8 \\
1.4\end{array}$ \\
\hline
\end{tabular}

* Each figure is the mean of 12 plants.

† Storage time $=12$ weeks.

Test 5 garlic was from a clonal line harvested from the field at Davis on July 29 to 30,1952 , and stored in slatted crates in the shade until placed in storage rooms on August 19. Seven units of bulbs were stored at each of the temperatures, $0^{\circ}, 5^{\circ}, 10^{\circ}, 15^{\circ}$, and $20^{\circ} \mathrm{C}$, and one unit from each temperature was planted in the field at Davis on the following dates (storage period is to the nearest week):

September 9 , after 3 weeks' storage ;

September 30 , after 6 weeks' storage ;

October 21, after 9 weeks' storage ;

November 11, after 12 weeks' storage;

December 15, after 17 weeks' storage;

January 5 , after 20 weeks' storage ;

February 2, after 24 weeks' storage.

Each storage unit consisted of six bulbs from which 40 cloves were planted. There were 35 units in all ( 5 storage temperatures $\mathrm{x} 7$ planting dates $\mathrm{x} 1$ clonal line).

Note: The garlic used in tests 6 through 9 and in test 11 was derived from five clonal lines planted in the field at Davis on February 20, 1953, har- 
vested on August 10 to 11, 1953, cured one week in the field, topped, and placed in a well-ventilated storage house. All samples to be stored were made up from two or more of these lines (as indicated in table 1) and were placed in storage rooms held at $0^{\circ}, 5^{\circ}, 10^{\circ}, 15^{\circ}$, and $20^{\circ} \mathrm{C}$, on August 20, 1953.

Test 6 consisted of six units of each of four lines placed in each storage room. One unit from each line and storage temperature was planted at Davis on each of the following dates in 1953-54 (storage period is to the nearest week) :

September 17, after 4 weeks' storage ;

October 15, after 8 weeks' storage;

November 12 , after 12 weeks' storage;

December 9 , after 16 weeks' storage;

January 6 , after 20 weeks' storage ;

February 4, after 24 weeks' storage.

Each storage unit consisted of 12 bulbs from which 60 cloves were planted. The test contained 120 units ( 5 storage temperatures $\mathrm{x} 6$ planting dates $\mathrm{x} 4$ clonal lines).

Test 7, conducted at the Meloland Station near El Centro in Imperial County, was similar in outline to test 6 , except that only two of the four clonal lines of the latter test were used. The history and storage of these lines are given above, and the planting dates (1953-54) were:

September 18;

October 16 ;

November 13 ;

December 10 ;

January 9 .

The number of days at the controlled storage temperatures prior to planting was four to seven days less than for the corresponding planting dates of test 6 because of time required to send the bulbs from Davis to Imperial County. Each unit consisted of 12 bulbs from which 60 cloves were planted. The test contained 50 units ( 5 storage temperatures $\mathrm{x} 5$ planting dates $\mathrm{x} 2$ clonal lines).

Test 8 was similar to test 6 , but was restricted to spring plantings since it was conducted in the cool Tulelake area in Siskiyou County. Two of the clonal lines used in test 6 (see p. 386) were selected. These lines were planted on April 1 and April 29, 1954, after 32 and 36 weeks of storage, respectively. Each unit consisted of 12 bulbs from which 60 cloves were planted. The test contained 20 units ( 5 storage temperatures $\mathrm{x} 2$ planting dates $\mathrm{x} 2$ clonal lines).

Test 9 was conducted in the commercial garlic growing area near San Juan Bautista, San Benito County. It was similar in original plan to test 6 , but was limited to plantings on December 15, 1953, January 11, and February 4,1954 , after approximately 17,21 , and 24 weeks' storage, respectively. Two of the clonal lines used in test 6 (see p. 386) were selected. Each unit consisted of 12 bulbs from which 60 cloves were planted. Test 9 contained 30 units ( 5 storage temperatures $\mathrm{x} 3$ planting dates $\mathrm{x} 2$ clonal lines).

Test 10 was located in the commercial garlic area near Gilroy, Santa Clara 
County. The two clonal lines used were not the same as those of tests 5 through 9, but had been handled in the same way (see note, p. 391) except that the $20^{\circ} \mathrm{C}$ storage was omitted. Lots were planted on December 3, 1953, January 6, and January 29, 1954, after approximately 15, 20, and 23 weeks of storage, respectively. Each unit contained 20 bulbs from which 20 feet of double-row bed were planted. The test contained 30 units (5 storage temperature $\mathrm{x} 3$ planting dates $\mathrm{x} 2$ clonal lines).

Test 11 was a field test at Davis, in which planting stock was stored successively at two temperatures before planting. The history of the garlic before storage was as outlined for test 6 . The test consisted of two parts, in the first of which four units (line 7-4) were stored at $20^{\circ} \mathrm{C}$ on August 20,1953 , and then shifted to $5^{\circ} \mathrm{C}$ eight weeks before planting. Planting dates were November 13, December 10, January 7, and February 4 (see table 4 ). In the second part of test 11 , four units (line 7-6) were placed at $5^{\circ} \mathrm{C}$ on August 20, and before planting on February 4, 1954, different units were given $0,1,2$, and 4 weeks of storage at $25^{\circ} \mathrm{C}$ (see table 5 ).

\section{Results of Field Tests}

In general, the most detailed data were obtained for test 6 at Davis, and this test is usually discussed first followed by comparisons with other tests at Davis and elsewhere in the state.

\section{EMERGENCE}

Data on emergence of plants in tests 5,6 , and 7 have been summarized by Mann and Lewis (1956, pp. 167-72). Since the emergence pattern of cloves affects later plant growth, discussed below, these data are briefly reviewed. Early sprouting of cloves was favored by storage of planting stock at $5^{\circ}$ to $15^{\circ} \mathrm{C}$ as compared with $0^{\circ}$ or $20^{\circ} \mathrm{C}$. Cloves from bulbs stored at $20^{\circ} \mathrm{C}$ generally sprouted last, those from $0^{\circ} \mathrm{C}$, next to last. The most effective storages for early emergence varied with the length of the storage period$10^{\circ}$ or $15^{\circ} \mathrm{C}$ was perhaps the most effective for the shorter storage periods, and $5^{\circ} \mathrm{C}$ for periods of three or four months or more. In laboratory sprouting trials, $5^{\circ} \mathrm{C}$ was almost consistently the most effective in decreasing rest. At all storage temperatures the level of rest appeared to decrease with time, although under field conditions this may be masked or changed by field temperatures.

\section{PLANT GROWTH}

Test 6. The effect of preplanting storage temperatures on plant growth is shown in figure 2, a photograph of one block of test 6 taken on March 6, 1954. The beds shown are not all of the same clonal line, but differences among lines were very slight.

On March 3, three days before the photograph was taken, the relative sizes of all units in the test were estimated visually, and measurements were taken on the units shown in figure 2. The measured heights ranged from 14 inches $\left(0^{\circ} \mathrm{C}\right.$, Nov. 12$)$ to 3 inches $\left(20^{\circ} \mathrm{C}, \mathrm{Feb} .4\right)$, and the block shown in the photograph proved to represent the whole test sufficiently well that figures on relative or absolute heights need not be given.

The relative heights of many of the units shown in figure 2 were continu- 


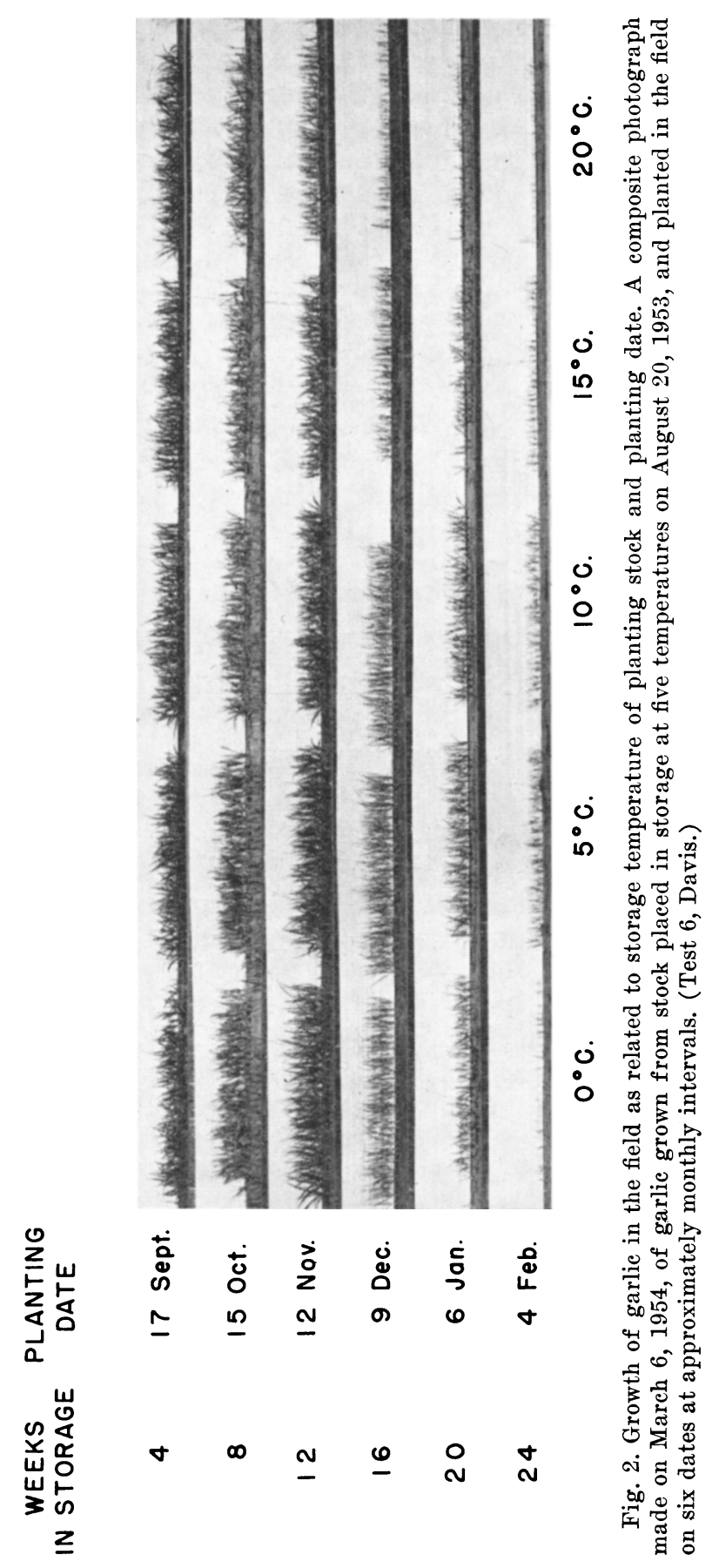


ally changing during the growing season. Nevertheless, several observations on this figure are of interest. The size of the units will be considered first in order of planting date and then according to storage temperature.

The September planting was preceded by four weeks of storage. This storage period had only a moderate effect on emergence (Mann and Lewis, 1956 , p. 169), and appears to be near the minimum to modify subsequent growth-all plantings of September were quite uniform in appearance.

The plantings of October and November show a striking and consistent decrease in plant size from the $0^{\circ}$ to the $20^{\circ} \mathrm{C}$ storage units, the differences between $5^{\circ}$ and $10^{\circ} \mathrm{C}$, and $10^{\circ}$ and $15^{\circ} \mathrm{C}$ being most conspicuous. For both of these planting dates, the $5^{\circ}$ and $10^{\circ} \mathrm{C}$ units emerged most quickly, so that a short time after emergence these plantings resembled the January and February plantings as they appear in figure 2. Vigorous growth of the $0^{\circ} \mathrm{C}$ units subsequent to sprouting overcame their initial small size.

In the December, January, and February plantings, as shown in figure 2, the $5^{\circ} \mathrm{C}$ units are tallest and the $20^{\circ} \mathrm{C}$ units shortest. The relative size of these units on March 6 reflects, to a considerable extent, the effect of preplanting storage temperatures on emergence time. These differences were not maintained throughout the growing season.

Comparing units by storage temperature, i.e., vertically in figure 2 , it is evident for the $15^{\circ}$ and $20^{\circ} \mathrm{C}$ units that the first plantings are the largest and that units are progressively smaller with later planting dates. On the other hand, for the $0^{\circ}$ and $5^{\circ} \mathrm{C}$ storages, the November plantings are tallest, and the units grade down in both directions from that date. Within the September, October, and November plantings it is evident that the $0^{\circ}$ and $5^{\circ} \mathrm{C}$ storages favored subsequent growth to the extent that continued storage, at least up to 12 weeks, more than made up for the delayed planting.

Apart from differences in size, the preplanting storage temperatures induced differences in growth habit. Except for the September plantings, plants from the $0^{\circ}$ and $20^{\circ} \mathrm{C}$ storages had slender false stems and narrow leaves, which gave them a spindly appearance. The plants from the $10^{\circ} \mathrm{C}$ storage were sturdy and compact, with thick false stems and broad leaf blades.

It is evident that the effects induced by storage temperature on rest and on growth resulted in quite distinet patterns. Leaf width followed a pattern similar to that of degree of rest, the $0^{\circ}$ and $20^{\circ} \mathrm{C}$ storage lots having much narrower leaves than lots stored at intermediate temperatures (particularly $10^{\circ} \mathrm{C}$ ). In contrast, the greater height of the lots from $5^{\circ}$ and $10^{\circ} \mathrm{C}$ storage immediately after emergence (rest effect) was soon overshadowed by the elongation of the $0^{\circ} \mathrm{C}$ storage lots, so that later there was a progressive decrease in plant height from the $0^{\circ}$ to $20^{\circ} \mathrm{C}$ storage lots (growth effect). With time, the plants in the taller units ceased to grow in height, and the shorter units caught up. Shortly before the drying and falling of tops associated with final maturity, the plot was more uniform in appearance than it had been earlier in the season.

Other tests. Where growth patterns were observed in other field tests, they were similar to those described above. Test 7 , for example, in the Imperial Valley, had a comparable emergence pattern (Mann and Lewis, 1956) 


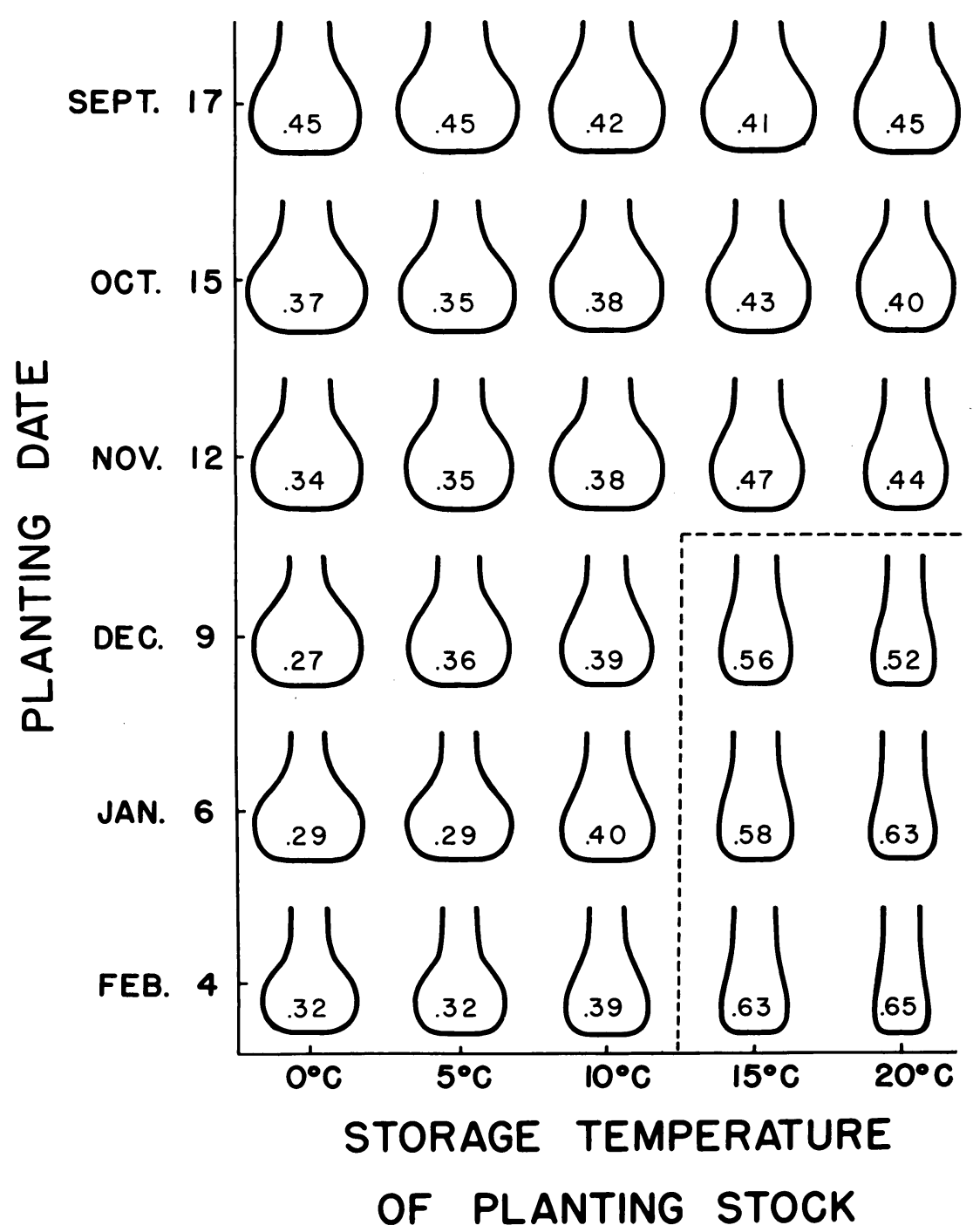

Fig. 3. Bulb shape and size in garlic as related to storage temperature of planting stock and planting date. Bulbs stored from August 20, 1953, to planting date. Observations taken May 18-19, 1954, before any lots were beginning to mature. Figure in each bulb is neck diameter/bulb diameter ratio based on 10 bulbs. Values below 0.50 (outside dotted line) indicate definite bulbing. Drawings are diagrammatic, but neck and bulb diameters are proportional to measured values. (Test 6 , Davis.)

followed by vigorous growth of the lots from low storage temperatures, so that after some time the units from $0^{\circ} \mathrm{C}$ were tallest and those from $20^{\circ} \mathrm{C}$ shortest. Growth habit of plants likewise differed with storage treatment as noted for test 6 (p. 395). 


\section{BULB DEVELOPMENT}

Test 6. On May 18 and 19 when plants of test 6 were nearly full size, but before any tops showed definite signs of maturity, the extent of bulbing was estimated by the neck diameter/bulb diameter ratios. Bulbs of 10 plants from each unit of one clonal line of test 6 were measured. Ratios determined individually for each of the 10 plants were averaged to give the mean values shown in figure 3. The bulb outlines in this figure are diagrammatic, but the neck and bulb diameters are proportional to the means represented.

Comparing the bulbs horizontally, i.e., within planting dates, it is seen that all units in the September planting (four weeks' storage) show essentially the same amount of bulbing. The October plantings are not uniform, bulbs from cloves stored at $15^{\circ}$ and $20^{\circ} \mathrm{C}$ showing less bulbing than those from the lower storage temperatures. The November and subsequent plantings resemble the October planting.

If bulbs from the same preplanting storage temperatures are compared (vertical rows of figure 3), it is evident that the $15^{\circ}$ and $20^{\circ} \mathrm{C}$ lots show progressively less bulbing with successively later planting dates. The $10^{\circ} \mathrm{C}$ lots show little change with planting dates, but the $0^{\circ}$ and $5^{\circ} \mathrm{C}$ units show the greatest amount of bulbing for the December or January plantings.

It appears that a delay in planting delayed bulb formation only if the bulbs were stored at temperatures above $10^{\circ} \mathrm{C}$. Holding bulbs at $0^{\circ}$ or $5^{\circ} \mathrm{C}$ favored bulbing to the extent that December and January plantings from those temperatures formed bulbs as quickly as or more quickly than earlier plantings.

The degree of bulbing parallels quite closely the plant-size data of figure 2, taken on March 6. However, the most advanced plants on May 19 and 20 were from the January or December rather than from the November planting date. This change is not unexpected, as it continues a trend already observed in March-the November plantings from the $0^{\circ}$ and $5^{\circ} \mathrm{C}$ storage were larger at that time than those planted in September and October. This parallel suggests a close relation between bulbing and early-season growth rate. On the contrary, neither bulbing nor plant growth rate responds to preplanting storage temperatures as does the change in level of rest. It will be recalled that rest decreases rapidly in bulbs stored at $5^{\circ}$ or $10^{\circ} \mathrm{C}$, but that at $0^{\circ} \mathrm{C}$ the level of rest drops slowly, much as it does in bulbs stored at $15^{\circ}$ or $20^{\circ} \mathrm{C}$.

Test 11. One of the greenhouse experiments, test 2, suggested that shifting bulbs from $5^{\circ}$ to $20^{\circ} \mathrm{C}$ storage for six weeks or more before planting can reduce the effectiveness of the $5^{\circ} \mathrm{C}$ storage. Similar treatments were tried in test 11, a field test, in which planting stock was exposed successively to two temperatures. In the first part of this test, bulbs stored at $20^{\circ} \mathrm{C}$ were shifted to $5^{\circ} \mathrm{C}$ for the final eight weeks of storage before planting. Bulbs were first placed in storage on August 20, as in test 6, and planting dates were about the same for the two tests, so that the results can be compared (table 4). The data in the right-hand half of table 4 show the mean neck/bulb ratios of 10 plants from each of the four planting dates of test 11. The left-hand part of table 4 shows bulbing data from the same clonal 
line taken from test 6 . These latter data correspond to those for the $0^{\circ}$ and $20^{\circ} \mathrm{C}$ storage shown in figure 3 , except that they represent a different clonal line.

Four weeks of storage have been shown to be near the minimum necessary to alter bulbing in garlic. Table 4 shows that eight weeks of storage at $5^{\circ} \mathrm{C}$ have a decided effect, as compared with storage at $20^{\circ} \mathrm{C}$, but that still longer periods of storage, as shown in the left-hand part of table 4, are much more effective. The effect on bulbing of the length of the storage period cannot be determined more precisely than this from the data at hand.

TABLE 4

BULB DEVELOPMENT IN GARLIC (NECK DIAMETER/BULB DIAMETER RATIOS) AS RELATED TO STORAGE TEMPERATURE OF PLANTING STOCK AND PLANTING DATE. DATA RECORDED MAY 19-20, 1954, BEFORE ANY PLANTS WERE BEGINNING TO MATURE

(Parts of tests 6 and 11, Davis)

\begin{tabular}{|c|c|c|c|c|c|c|c|c|}
\hline \multirow{3}{*}{$\begin{array}{c}\text { Planting date } \\
\text { (test } 6)\end{array}$} & \multirow{3}{*}{$\begin{array}{l}\text { Weeks in } \\
\text { storage }^{*}\end{array}$} & \multirow{2}{*}{\multicolumn{2}{|c|}{$\frac{\text { Neck/bulb ratios } \dagger}{\text { Storage temperature }}$}} & \multirow{3}{*}{$\begin{array}{c}\text { Planting date } \\
\text { (test 11) }\end{array}$} & \multicolumn{3}{|c|}{ Storage of planting stocks* } & \multirow{3}{*}{$\begin{array}{c}\text { Neck/bulb } \\
\text { ratios } \dagger\end{array}$} \\
\hline & & & & & \multirow{2}{*}{$\begin{array}{l}\text { Weeks at } \\
20^{\circ} \mathrm{C}\end{array}$} & \multirow{2}{*}{$\begin{array}{l}\text { Weeks at } \\
5^{\circ} \mathrm{C}\end{array}$} & \multirow{2}{*}{$\begin{array}{l}\text { Total } \\
\text { weeks }\end{array}$} & \\
\hline & & $5^{\circ} \mathrm{C}$ & $20^{\circ} \mathrm{C}$ & & & & & \\
\hline Sept. $17 \ldots$ & 4 & 0.44 & 0.39 & & . & .. & . & $\ldots$ \\
\hline Oct. $15 \ldots \ldots \ldots$ & 8 & 0.33 & 0.41 & $\ldots \ldots$ & . & .. & .. & $\ldots$ \\
\hline Nov. $12 \ldots \ldots$ & 12 & 0.33 & 0.46 & Nov. $13 \ldots$ & 4 & 8 & 12 & 0.34 \\
\hline Dec. $9 \ldots$ & 16 & 0.30 & 0.59 & Dec. $10 \ldots \ldots$ & 8 & 8 & 16 & 0.34 \\
\hline Jan. 6..... & 20 & 0.29 & 0.70 & Jan. $7 \ldots \ldots \ldots$ & 12 & 8 & 20 & 0.41 \\
\hline Feb. $4 \ldots$ & 24 & 0.32 & 0.67 & Feb. $4 \ldots \ldots \ldots$ & 16 & 8 & 24 & 0.57 \\
\hline
\end{tabular}

* All plants grown from bulbs stored from August 20, 1953, until planting.

$\dagger$ Each figure is a mean of 10 bulbs.

The reversibility of the effect of low-temperature storage by subsequent exposure to high temperature was confirmed in the second part of test 11 by placing bulbs in $5^{\circ} \mathrm{C}$ storage on August 20 and then transferring them to $25^{\circ} \mathrm{C}$ for $0,1,2$, and 4 weeks before planting on February 4 . Neck/bulb ratios from measurements on May 24 are shown in table 5. One and two weeks at $25^{\circ} \mathrm{C}$ had little or no effect, but four weeks definitely reduced bulbing.

In tests of this type, in which bulbs are exposed successively to two temperatures, it is difficult to avoid some confounding since, as exposure to one temperature is shortened or lengthened, exposure to another temperature must be changed in an opposite direction. A similar difficulty exists with shifting planting dates since both length of storage and field conditions change at the same time. However, the striking responses of garlic to storage periods of equal length but at different temperatures appear to give a reasonable basis for the interpretation of these more complex treatments.

Test 4. If low temperature is necessary for bulb formation, it might be assumed that plants from bulbs stored at high temperatures would fail to bulb if planted in the field in late spring after cool weather is past. This assumption was checked by test 4 in which bulbs were stored at $0^{\circ}, 5^{\circ}, 10^{\circ}$, $15^{\circ}, 20^{\circ}$, and $25^{\circ} \mathrm{C}$ from August, 1952, until the cloves were planted on 


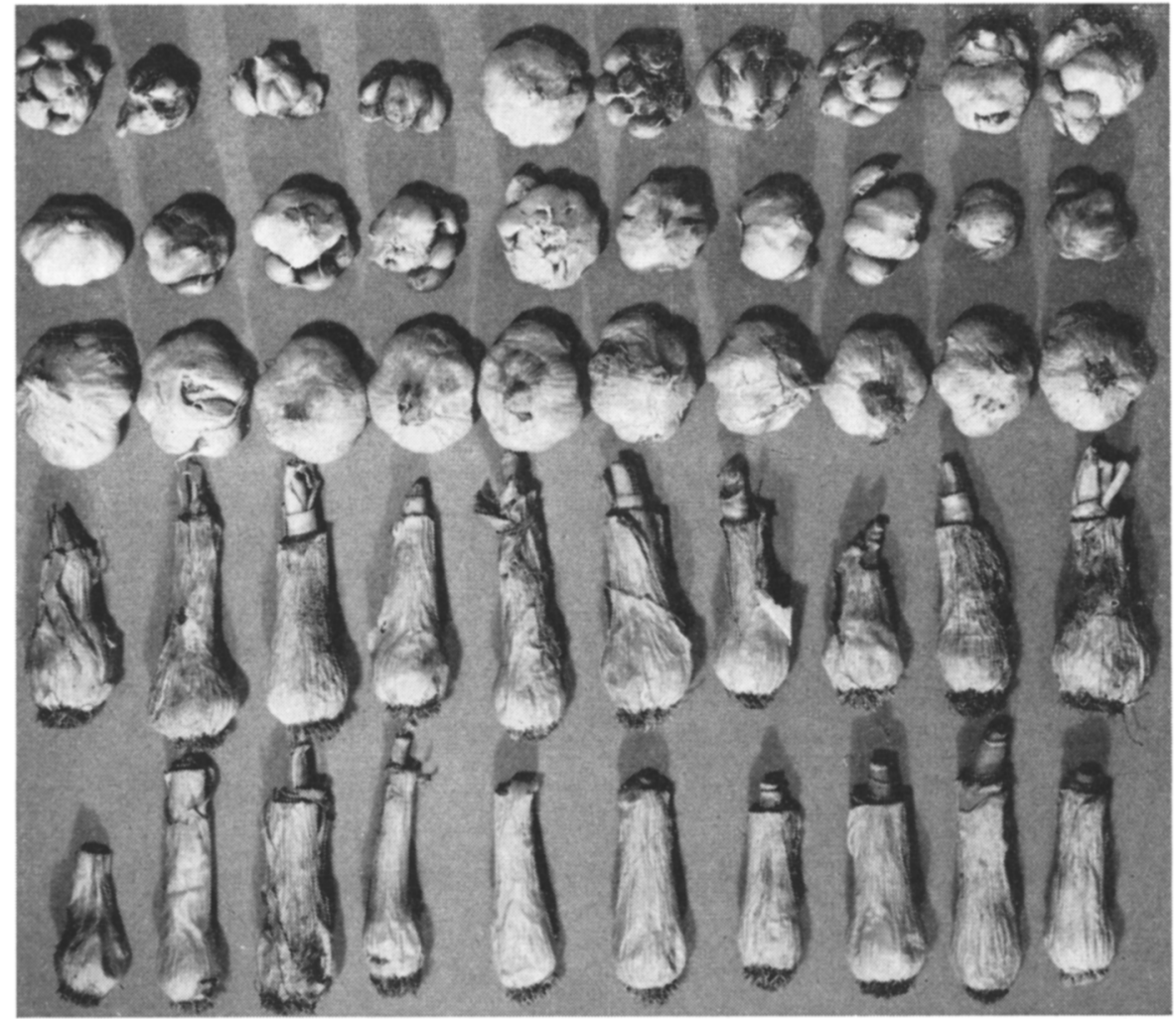

Fig. 4. Bulb development in garlic in relation to storage temperature of planting stock. Storage temperature, top to bottom: $0^{\circ}, 5^{\circ}, 10^{\circ}, 15^{\circ}, 20^{\circ} \mathrm{C}$. Bulbs grown from a planting of April 29, 1954, after nine months of storage. Lots stored at $15^{\circ}$ and $20^{\circ} \mathrm{C}$ had not received sufficient low temperature to form bulbs. (Test 8, Tulelake Field Station.) (Photograph by B. J. Hoyle.)

June 3, 1953. Table 6 gives data on the maturity and clove formation of these plants at the time of harvest, September 5, 1953. All plants were small, and in no lot did the mean bulb weight exceed 4.0 grams. It is clear that plants produced from cloves stored at $15^{\circ} \mathrm{C}$ or above, and planted in the field in early June, were unable to mature. Differences in number of cloves per bulb were evident among plants grown from cloves stored at $0^{\circ}, 5^{\circ}$, and $10^{\circ} \mathrm{C}$ before planting, but not among those from cloves stored at $15^{\circ}$, $20^{\circ}$, and $25^{\circ} \mathrm{C}$.

Test 8. Figure 4, from test 8 at the Tulelake Field Station, Siskiyou County, shows strikingly the effect of storage temperature on bulb formation. The cloves from which these bulbs were grown had been in storage for nine months, and were planted on April 29, 1954, when the days were already quite long. Weekly mean temperatures after that date were mostly above $10^{\circ} \mathrm{C}\left(50^{\circ} \mathrm{F}\right)$, and from mid-June to early August were above $16^{\circ} \mathrm{C}$ $\left(60^{\circ} \mathrm{F}\right)$. The lots from $0^{\circ}, 5^{\circ}$, and $10^{\circ} \mathrm{C}$ storage all reached full maturity by mid-September or before, but the $15^{\circ}$ and $20^{\circ} \mathrm{C}$ storage lots were still 
green in mid-October although they had been exposed to summer day lengths of over 15 hours at about $42^{\circ}$ latitude.

\section{MATURITY DATES}

Maturity in garlic follows formation of the bulb and is recognized in the field by the falling-over and drying of the tops. As maturation is gradual, it is difficult to select a definite day on which a plant or group of plants reaches maturity.

TABLE 5

BULB DEVELOPMENT AND DATE OF MATURITY IN GARLIC IN RELATION TO STORAGE TEMPERATURE OF PLANTING STOCK

(Part of test 11, Davis)

\begin{tabular}{c|c|c|c|c}
\hline \hline \multicolumn{2}{c|}{ Storage of planting stocks* } & Neck/bulb \\
$\begin{array}{c}\text { Weeks at } \\
5^{\circ} \mathrm{C}\end{array}$ & $\begin{array}{c}\text { Weeks at } \\
25^{\circ} \mathrm{C}\end{array}$ & $\begin{array}{c}\text { Total } \\
\text { weeks }\end{array}$ & $\begin{array}{c}\text { Date of full } \\
\text { maturity }\end{array}$ \\
\hline 24 & 0 & 24 & 0.32 & July 14 \\
23 & 1 & 24 & 0.29 & July 16 \\
22 & 2 & 24 & 0.35 & July 16 \\
20 & 4 & 24 & 0.48 & July 28 \\
\hline
\end{tabular}

* Planting stock held at controlled temperatures, as indicated, from August 20, 1953. until planting on February 4, 1954 .

$\dagger$ Observed May 24,1954, before any plants were beginning to mature. Each figure is a mean of 10 bulbs.

To make the estimation of maturity more reliable, all of the units in several of the tests were rated weekly from the first signs of maturity until all units were mature. Four grades of maturity were used in addition to the rating "fully mature," as follows:

$0 \quad$ Green, the tops erect and green; only the older leaves or leaf tips dry. Plants appear to be actively growing.

$1 \quad$ Intermediate, between 0 and 2.

2 Half mature, the tops showing considerable drying. Some tops may have begun to fall over.

$3 \quad$ Intermediate, between 2 and 4.

4 Fully mature, the tops mostly down, or brown and dry, or both. Growth has ceased and plants are ready to harvest.

Test 6. Maturity ratings were first taken on June 3 and then weekly for the next 16 weeks. The histogram in figure $5 \mathrm{~A}$ presents a portion of these maturity ratings. Each bar represents the average of four clonal lines. To save space, the data presented are limited to those of four alternate weeks during the period when most lots were maturing. Two units, the $15^{\circ}$ and $20^{\circ} \mathrm{C}$ storage lots planted on February 4 , are not represented in the selected data. Those lots did not show evidence of maturity until July 21 and August 4, and reached full maturity on August 11 and September 22, respectively.

Most lots (25 of 30) changed from green to fully mature over a period of 5 to 6 weeks and, as indicated by figure $5 \mathrm{~A}$, these changes proceeded con- 
sistently and uniformly between the 0 and 4 ratings. These observations give greater confidence in the data presented in figure 6 , the full maturity dates for all units.

The curves in figure 6 show the dates of full maturity as influenced by planting date and preplanting storage temperature. All curves are similar in shape except those representing the plantings of September and February. The September plantings all came to full maturity at the same time; either the month of preplanting storage received by these lots was too short to have much effect on maturity or the effects were reversed by high field temperatures subsequent to planting. The mean U. S. Weather Bureau air temperature at Davis for the period between the planting of September 17 and October 15 was slightly less than $20^{\circ} \mathrm{C}\left(68^{\circ} \mathrm{F}\right)$. The February plantings showed a great variation in time of maturity. They had received six months of preplanting storage, and were planted so late that the cloves from the higher storage temperatures received little exposure to cold and were slow to form bulbs and mature-those from $20^{\circ} \mathrm{C}$ storage almost failed to do so.

Except for the cloves from $15^{\circ}$ and $20^{\circ} \mathrm{C}$ storage planted in February, all lots matured between June 30 and August 4, a period of about five weeks. Since the extreme planting dates were 20 weeks apart (September 17 to February 4), it is evident that lots tended to mature at about the same time regardless of planting date. This is, of course, a common observation with many crop plants. The time from planting to maturity varied from a minimum of 160 days (February planting, $0^{\circ}$ and $5^{\circ} \mathrm{C}$ storage) to a maximum of 300 days (September planting, all storages). Since wide differences in planting dates resulted in relatively small differences in harvest dates, and since both of the above plantings matured on July 14, the great range in days from planting to maturity observed here resulted almost entirely from differences in planting dates.

On the other hand, if the range in maturity dates alone is considered, there appears to be a clear relation between planting date and maturity. Except for the September planting, where the four weeks of storage had little effect on maturity date, early planting favored early maturity. Comparing all units receiving the same preplanting storage temperature, each successive planting matured as late as or later than the previous one. Considering the plantings of October through January, a month's delay in planting delayed maturity by from three to four days $\left(0^{\circ}\right.$ and $5^{\circ} \mathrm{C}$ storage $)$ to about a week $\left(15^{\circ}\right.$ and $20^{\circ} \mathrm{C}$ storage). The February curve indicates that these relationships would continue for later planting dates, but with greater delays in maturity for storages at $10^{\circ} \mathrm{C}$ or above.

Excluding again the September planting, and comparing lots within each planting date, we find a rather consistent delaying of maturity date as preplanting storage temperatures were increased. Lots stored at $0^{\circ}$ and $5^{\circ} \mathrm{C}$ matured first, with no difference between them. Lots stored at $10^{\circ} \mathrm{C}$ matured about one week later than those from $0^{\circ}$ and $5^{\circ} \mathrm{C}$, and those from $15^{\circ}$ and $20^{\circ} \mathrm{C}$ an additional week or two weeks later. Except for the January and February plantings, lots stored at $15^{\circ}$ and $20^{\circ} \mathrm{C}$ matured at the same time. 
STAGE OF MATURITY ON:

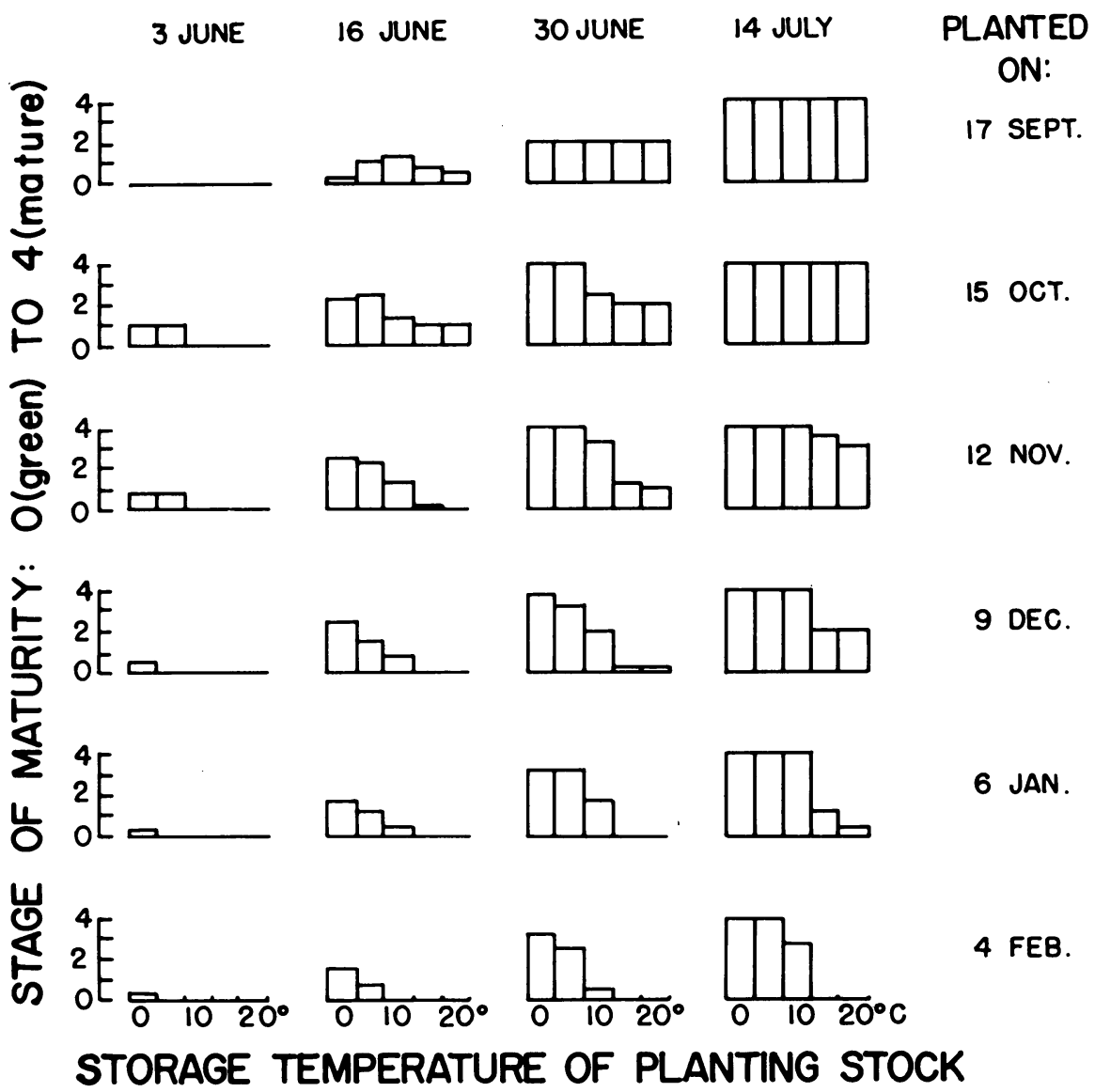

Fig. 5A. Maturity stages of field-grown garlic in relation to storage temperature of planting stock and planting date. Planting stock was stored at $0^{\circ}, 5^{\circ}, 10^{\circ}, 15^{\circ}$, and $20^{\circ} \mathrm{C}$ from August 20, 1953, until indicated planting dates. Data were taken weekly; only those for alternate weeks are shown. Maturity was rated visually on a scale extending from green (0) to fully mature (4). (Test 6, Davis.)

Test 7. Maturity data on test 7 at the Meloland Station in Imperial Valley were taken in the same way as described above for test 6 at Davis. Stages of maturity for four alternate weeks are shown in figure 5B, and the final maturity dates in table 7 .

Test 7 included five planting dates and two clonal lines, not six planting dates and four clonal lines as in test 6 , and as noted under "Materials and Methods," page 392, the storage periods at controlled temperatures in test 7 were 4 to 7 days less than in test 6 . In 1953-54 the mean weekly temperatures calculated from U. S. Weather Bureau data for El Centro, about 6 miles from the Meloland Station, fell rapidly from $21^{\circ} \mathrm{C}\left(70^{\circ} \mathrm{F}\right)$ at the beginning of November to a minimum of $10.5^{\circ} \mathrm{C}\left(51^{\circ} \mathrm{F}\right)$ late in December, 


\section{STAGE OF MATURITY ON:}

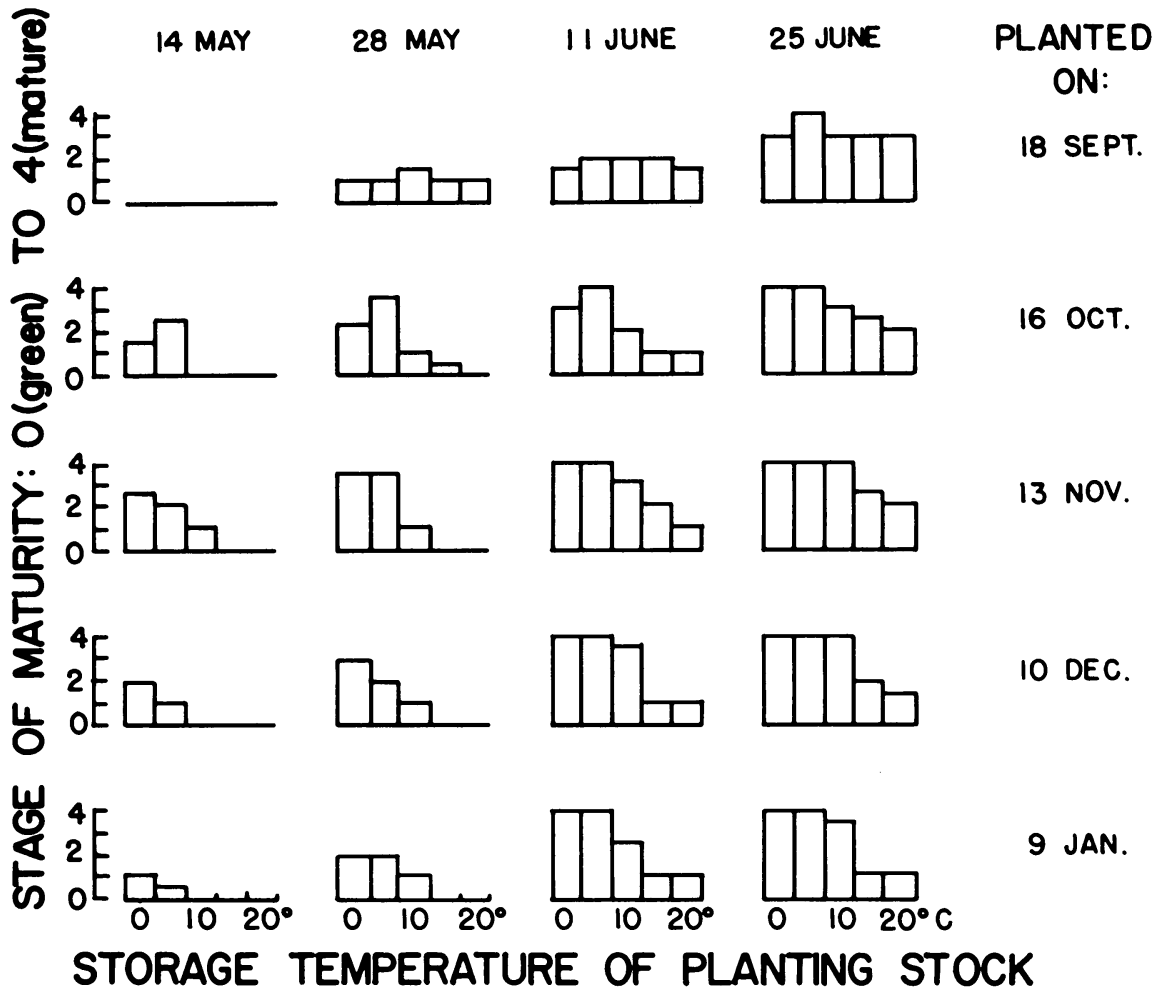

Fig. 5B. Maturity stages of field-grown garlic in relation to storage temperature of planting stock and planting date. Planting stock was stored at $0^{\circ}, 5^{\circ}, 10^{\circ}, 15^{\circ}$ and $20^{\circ} \mathrm{C}$ from August 20, 1953, until indicated planting dates. Data were taken weekly; only those for alternate weeks are shown. Maturity was rated visually on a scale extending from green (0) to fully mature (4). (Test 7, Meloland.)

and then rose irregularly, reaching $21^{\circ} \mathrm{C}\left(70^{\circ} \mathrm{F}\right)$ again about the last of May. Under these conditions, plants grown from bulbs held at $20^{\circ} \mathrm{C}$ and planted November 13 did not form usable bulbs, nor did the $15^{\circ}$ or $20^{\circ} \mathrm{C}$ storage lots planted December 10 and January 9. For this reason maturity dates for these lots may not be strictly comparable with the dates for the lots which did form bulbs, and they are therefore omitted from table 7 .

The maturity responses of test 7 in general resemble those of test 6 . The September planting showed little effect of storage, but with the longer storages, maturity was later with the higher storage tempertaures. The time of maturity was markedly affected by storage temperature over the intermediate range, $5^{\circ}, 10^{\circ}$, and $15^{\circ} \mathrm{C}$. Plants grown from bulbs stored at $0^{\circ}$ and $5^{\circ} \mathrm{C}$ matured at about the same time except for the October planting in which plants from bulbs held at $5^{\circ} \mathrm{C}$ matured between three and four weeks earlier than those from bulbs held at $0^{\circ} \mathrm{C}$ storage. It appears that a storage period of about two months at $5^{\circ} \mathrm{C}$ may be more favorable to early maturity than storage at $0^{\circ} \mathrm{C}$, but that early maturity actually occurs only 
if subsequent growing conditions are favorable. Plants grown from bulbs held at $15^{\circ}$ and $20^{\circ} \mathrm{C}$ also matured at nearly the same times. Planting date had somewhat less effect on date of maturity than in test 6 , but the effect of storage temperature was greater as might be expected where field temperatures were rarely below $10^{\circ} \mathrm{C}\left(50^{\circ} \mathrm{F}\right)$.

Other tests. Observations on maturity were also made on tests $1,3,5,8$, 9 , and 11. Data from these tests, while generally less complete than those for tests 6 and 7 , followed the pattern of the latter tests and, except for certain points, will not be presented in detail.

TABLE 6

RESPONSE OF GARLIC TO LATE PLANTING. TEN CLOVES PLANTED IN

THE FIELD ON JUNE 3, 1953, FROM BULBS STORED AT INDICATED

TEMPERATURES SINCE AUGUST 26, 1952. ALL DATA RECORDED

AT TIME OF HARVEST, SEPTEMBER 5, 1953

(Test 4, Davis)

\begin{tabular}{c|c|c|c|c}
\hline \hline \multirow{2}{*}{$\begin{array}{c}\text { Storage temp. } \\
\text { of } \\
\text { planting stock }\end{array}$} & \multicolumn{3}{|c|}{ No. of bulbs with: } & \multicolumn{1}{c}{$\begin{array}{c}\text { Maturity of plants } \\
\text { at harvest }\end{array}$} \\
\cline { 2 - 3 } $\begin{array}{c}\text { Several } \\
\text { cloves }\end{array}$ & $\begin{array}{c}\text { One } \\
\text { clove }\end{array}$ & $\begin{array}{c}\text { No } \\
\text { cloves }\end{array}$ & \\
\hline Centigrade & & & & Mature; tops dry \\
$0^{\circ}$ & 9 & 0 & 0 & Mature; tops dry \\
$5^{\circ}$ & 6 & 3 & 0 & Mature; tops dry \\
$10^{\circ}$ & 1 & 9 & 0 & Growing; tops green \\
$15^{\circ}$ & 2 & 3 & 5 & Growing; tops green \\
$20^{\circ}$ & 0 & 4 & 5 & Growing; tops green \\
$25^{\circ}$ & 2 & 3 & 5 &
\end{tabular}

In test 11, as noted above, exposure of bulbs to $25^{\circ} \mathrm{C}$ for a few weeks following preplanting storage at $5^{\circ} \mathrm{C}$ decreased the bulbing of the plants (table 5). Maturity dates in table 5 show that the four-week exposure to $25^{\circ} \mathrm{C}$ also caused a considerable delay in maturity.

The two plantings of test 8 in the cool Tulelake area are of interest in that they were made late in the spring, on April 1 and April 29, after storage periods of 32 and 36 weeks. Plants from bulbs stored at $0^{\circ}, 5^{\circ}$, and $10^{\circ} \mathrm{C}$ matured in that order and with little difference between the two planting dates, but as shown in figure 4, the plants from bulbs stored at $15^{\circ}$ and $20^{\circ} \mathrm{C}$ failed to mature. These plantings responded in the same manner as the December and January plantings from $15^{\circ}$ and $20^{\circ} \mathrm{C}$ storage made at the Meloland Station in the Imperial Valley (test 7).

As noted above, the October planting of test 7 suggested that, for storage periods of around two months, storage at $5^{\circ} \mathrm{C}$ may favor early maturity more than storage at $0^{\circ} \mathrm{C}$. This was not observed in test 6 , but was shown by the data of tests 1,3 , and 5 .

In test 1 , a greenhouse test described earlier, plants from bulbs stored for one, two, and three months at $5^{\circ} \mathrm{C}$ all matured a few days earlier than comparable lots from $0^{\circ} \mathrm{C}$ storage. In test 3 , also a greenhouse test, plants from bulbs stored at $5^{\circ} \mathrm{C}$ matured three days later than comparable lots stored at $0^{\circ} \mathrm{C}$ (see table 3 ). This time difference, however, was nonsignifi- 
cant (t-test, Snedecor, 1946), but bulb formation, as measured by neck diameter/bulb diameter, was consistently more advanced in plants from bulbs stored at $5^{\circ} \mathrm{C}$ (see fig. 1, p. 390).

Again in test 5 , plants from bulbs stored at $5^{\circ}$ and $10^{\circ} \mathrm{C}$ for 6 or 9 weeks (plantings of September 30 and October 21) matured earlier than did plants from bulbs stored at $0^{\circ} \mathrm{C}$. For the shortest storage period (three weeks) and for storage periods of 17 weeks or more, the plants from bulbs stored at $0^{\circ} \mathrm{C}$ matured well ahead of those from bulbs stored at higher temperatures.

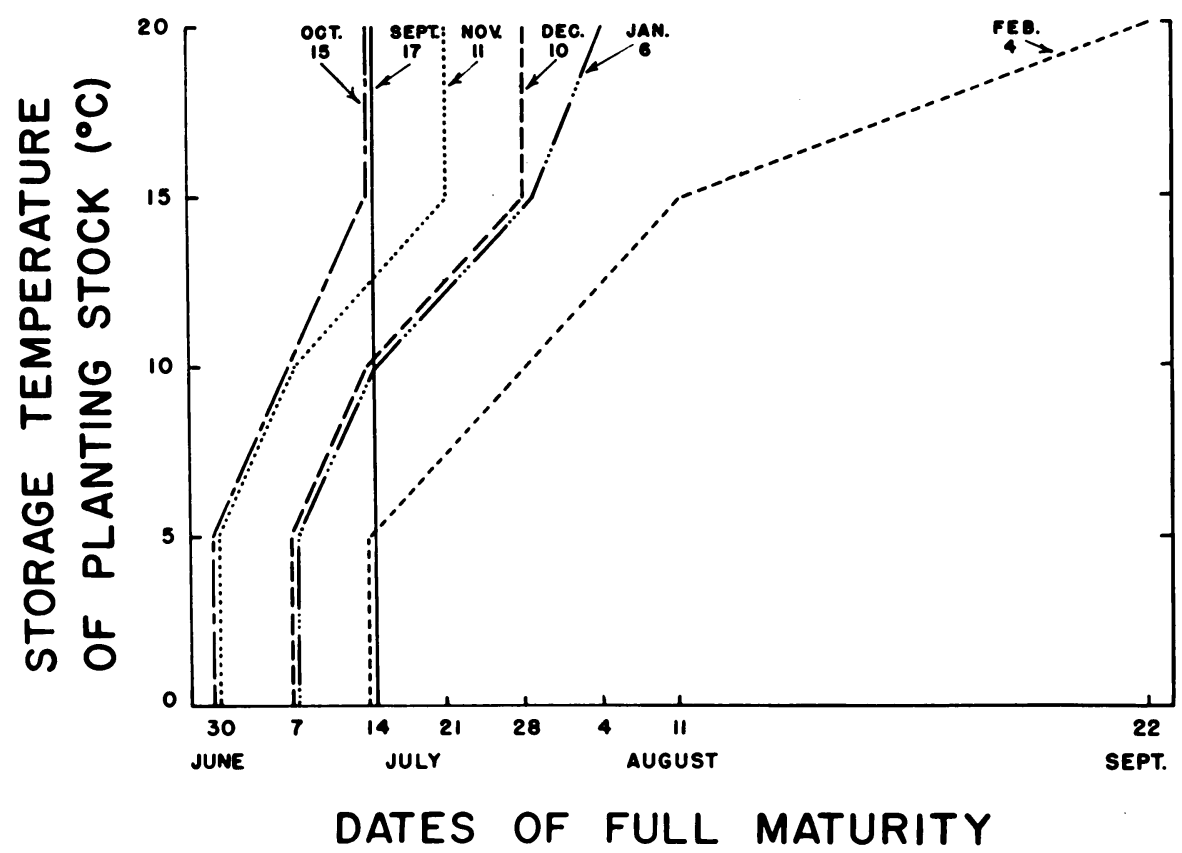

Fig. 6. Final maturity dates of field-grown garlic in relation to storage temperature of planting stock and planting date. Each curve represents a separate planting date. Cloves were planted from bulbs stored at $0^{\circ}, 5^{\circ}, 10^{\circ}, 15^{\circ}$, and $20^{\circ} \mathrm{C}$ from August 20, 1953, until indicated planting date. (Test 6 , Davis.)

\section{BULB ROUGHNESS AND VISIBLE LATERAL SHOOTS}

Bulbs which have large exterior cloves with few or no dry leaf bases surrounding them are usually termed rough. Heavy soils which become dry at the surface may cause misshapen bulbs, and removal of leaf bases by rotting or mechanical means may increase roughness. However, apart from these factors, roughness appears to be the result of growth responses to low temperatures experienced either before or after planting.

Figure 7 from test 5 illustrates smooth and rough bulbs. Bulbs were classified as rough, irregular, or smooth. Rough bulbs had exposed cloves, irregular bulbs lacked exposed cloves but were at least as irregular in shape as the arbitrary standard bulb shown in figure 8, and smooth bulbs had no exposed cloves and were more regular than the bulb in figure 8. Doubles, 

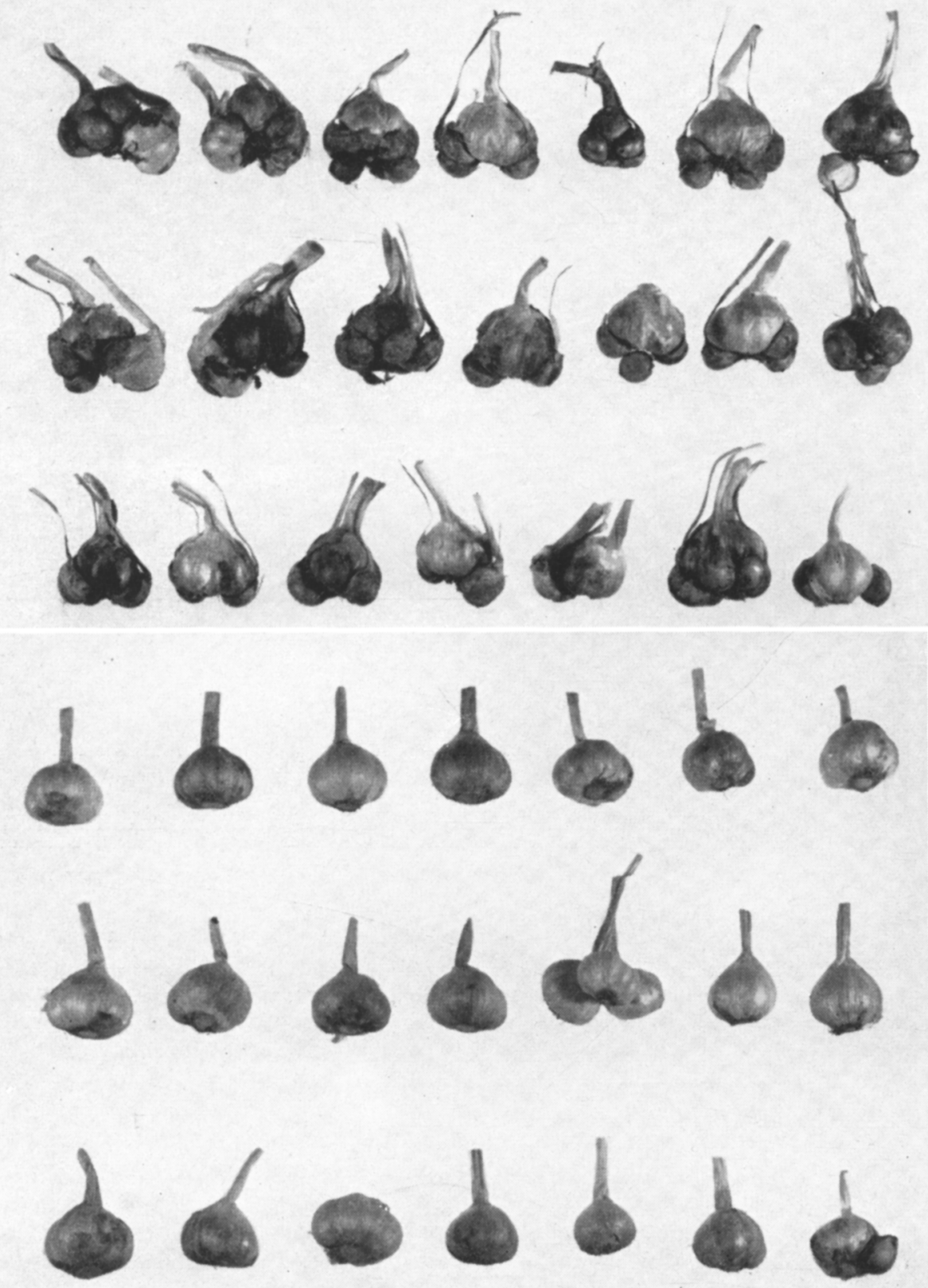

Fig. 7. Rough and smooth garlic. Top: bulbs planted October 21, 1952, from planting stock stored at $5^{\circ} \mathrm{C}$ for nine weeks; all are rough. Note that small side bulbs have separate tops. These are axillary shoots, tips of which are visible in green, immature plants. Bottom: bulbs planted September 30, 1952, from planting stock stored at $20^{\circ} \mathrm{C}$ for six weeks; most are smooth. (Test 5, Davis.) 
i.e., bulbs with two fairly equal but separate parts which result from planting cloves with two shoot apices, were classified as rough, irregular, or smooth according to the appearance of the parts. Since, in presenting data, a single figure is most convenient for representing degree of roughness, a percentage figure which seemed to represent best the visual appearance of the lots was obtained by adding one half of the number of irregular bulbs to all the rough bulbs and expressing this figure as a percentage of the total.

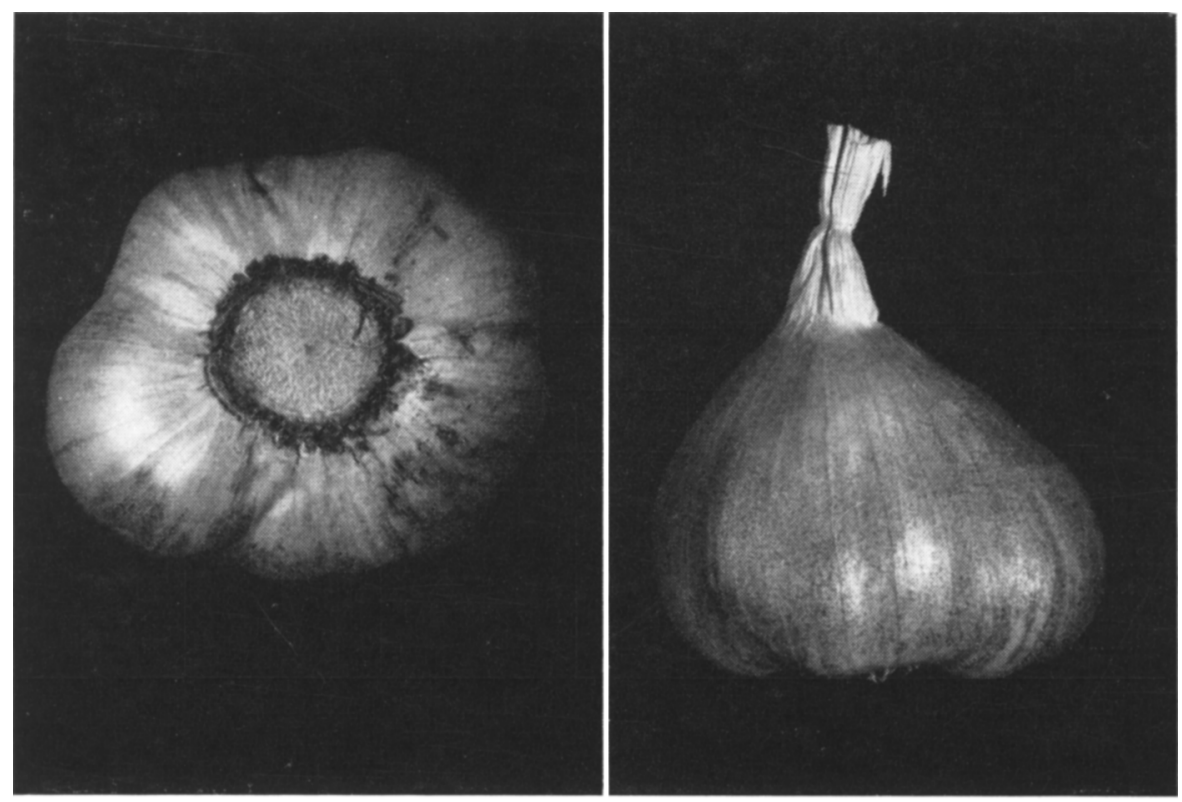

Fig. 8. Garlic bulb selected as arbitrary standard of shape. Bulbs as irregular as or more irregular than this bulb, but without exposed surface cloves, were classed as irregular (see text).

Garlic plants which will produce rough bulbs at maturity can usually be recognized during early stages of growth by the presence of shoots exserted from the axils of the foliage leaves. These shoots are the outer leaves of cloves or groups of cloves in the leaf axils. Ordinarily these leaves are short and bladeless, sheathing the cloves, but not extending much beyond them (Mann, 1952). Under certain conditions, however, they develop green blades which elongate and are exserted from the sheaths of the subtending leaves. The necks of such plants are usually thick and firm because of the additional leaves, and the bulbs, at maturity, are almost invariably rough. Garlic growers term such plants "stiff-necks." The bases of these elongated, lateral shoots on mature rough bulbs are shown in figure 7, top.

Test 6. Data from this test, presented in table 8, illustrate well the pattern of bulb roughness as associated with planting date and storage temperature of planting stock.

The most conspicuous variation in the amount of roughness is its decrease as planting date is delayed. Storage temperature of planting stock also af- 
fects roughness, but in test 6 its effect became evident only as the exposure to low temperature in the field decreased and the length of the preplanting storage period increased. For plantings of December and later, the bulbs from cloves stored at $0^{\circ}$ and $5^{\circ} \mathrm{C}$ were rougher than those from cloves stored at $15^{\circ}$ and $20^{\circ} \mathrm{C}$.

In many plants of test 6 the green shoots described above were visible in the axils of the leaves. Data on their occurrence were recorded on June 11, and are summarized in table 8 . These data show that as with roughness, the frequency of visible lateral shoots decreased as the planting date was delayed, and that there were fewer lateral shoots from cloves held at high storage temperatures before planting.

\section{TABLE 7}

FINAL MATURITY DATES OF FIELD-GROWN GARLIC IN RELATION TO STORAGE TEMPERATURE OF PLANTING STOCK AND PLANTING DATE

(Test 7, Meloland)

\begin{tabular}{|c|c|c|c|c|c|}
\hline \multirow{2}{*}{ Storage temp. of planting stock* } & \multicolumn{5}{|c|}{ Planting dates, 1953-54 } \\
\hline & Sept. 9 & Oct. 16 & Nov. 13 & Dec. 10 & Jan. 9 \\
\hline Centigrade & \multicolumn{5}{|c|}{ Dates of full maturity, 1954} \\
\hline 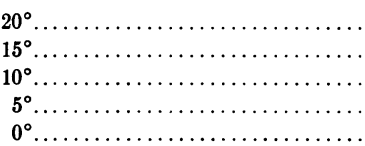 & $\begin{array}{l}\text { July } 2 \\
\text { July } 2 \\
\text { July } 2 \\
\text { June } 25 \\
\text { July } 2\end{array}$ & $\begin{array}{l}\text { July } 9 \\
\text { July } 6 \\
\text { July } 2 \\
\text { May } 30 \\
\text { June 25 }\end{array}$ & $\begin{array}{l}\text { no bulbs formed } \\
\text { July } 6 \\
\text { June } 21 \\
\text { May } 30 \\
\text { May } 30\end{array}$ & $\begin{array}{l}\text { no bulbs formed } \\
\text { no bulbs formed } \\
\text { June } 13 \\
\text { June } 4 \\
\text { May } 30\end{array}$ & $\begin{array}{l}\text { no bulbs formed } \\
\text { no bulbs formed } \\
\text { July } 29 \\
\text { June } 4 \\
\text { June } 4\end{array}$ \\
\hline
\end{tabular}

* Cloves were from bulbs stored from August 20,1953, until indicated planting date.

The lines in the two parts of table 8, one separating roughness at the 50 per cent level and the other separating lateral shoots at the 90 per cent level, emphasize the decrease in both roughness and visible laterals with delayed planting date and with the higher storage temperatures of planting stock.

The position of the visible lateral shoots within the plant is of interest. This was determined by counting and tagging leaves of young plants before any outer leaves were lost, and then later counting from the known leaves to the outermost leaf in which an elongated shoot appeared. Considering the first leaf with a green blade as leaf 1 (this corresponds to leaf 4 , Plate 2,E, Mann, 1952), and continuing inward to younger leaves, the position of the outermost shoot was found to be as indicated in table 9 . These data show that the higher the preplanting storage temperature, the further toward the center of the bulb the shoots appear. Low-temperature storage before planting not only induces elongation of clove parts into green leaves, but also induces the formation of cloves in leaves nearer the bulb surface, thus explaining the association of low temperature and roughness. This observation recalls tables 3 and 6 , the data from both of which indicate that exposure to low temperature is associated with clove initiation.

Test 5. Bulb roughness in test 5, as related to planting date and storage temperature of planting stock, is shown in the upper graph of figure 9 . 
Figure 7, illustrating rough and smooth bulbs, represents two units of this test. Roughness of bulbs was measured in the same way as in test 6 , above. These data agree with those of test 6 in showing a similar effect of lowtemperature storage on roughness. However, the September planting was strikingly less rough in test 5 than in test 6 , and this was also true of the February planting from the $0^{\circ}$ and $5^{\circ} \mathrm{C}$ storages. With respect to roughness, the plantings responded as if field temperatures had the greater effect on roughness in test 6 , while storage temperatures had the predominant effect in test 5 . Field temperatures at Davis during the two seasons were

TABLE 8

BULB ROUGHNESS OF MATURE GARLIC AND PERCENTAGE OF GROWING PLANTS WITH VISIBLE LATERAL SHOOTS IN RELATION TO PLANTING

DATE AND STORAGE TEMPERATURE OF PLANTING STOCK. EACH FIGURE IS THE AVERAGE OF FOUR CLONAL LINES AND IS BASED ON TOTALS OF 207 TO 239 PLANTS

(Test 6, Davis)

\begin{tabular}{|c|c|c|c|c|c|c|c|c|c|c|}
\hline \multirow{3}{*}{ Planting date } & \multicolumn{5}{|c|}{ Roughness, mature bulbs } & \multirow{2}{*}{\multicolumn{5}{|c|}{$\begin{array}{c}\text { Plants with visible lateral shoots or } \\
\text { June } 11\end{array}$}} \\
\hline & \multicolumn{5}{|c|}{ Storage temp. of planting stock $\left({ }^{\circ} \mathrm{C}\right)$} & Storage temp. of planting stock $\left({ }^{\circ} \mathrm{C}\right)$ & & & & \\
\hline & $0^{\circ}$ & $5^{\circ}$ & $10^{\circ}$ & $15^{\circ}$ & $20^{\circ}$ & $0^{\circ}$ & $5^{\circ}$ & $10^{\circ}$ & $15^{\circ}$ & $20^{\circ}$ \\
\hline & \multicolumn{5}{|c|}{ per cent } & \multicolumn{5}{|c|}{ per cent } \\
\hline Sept. 17 . & 93 & 95 & 95 & 87 & 89 & 98 & 97 & 97 & 91 & 96 \\
\hline Oct. 12 . & 77 & 80 & 94 & 85 & 82 & 99 & 97 & 100 & 90 & 88 \\
\hline Nov. 12 . & 58 & 74 & 81 & 69 & 46 & 94 & 100 & 92 & 72 & 34 \\
\hline Dec. 9. & 70 & 72 & 62 & 16 & 18 & 95 & 91 & 63 & 22 & 24 \\
\hline Jan. 6.. & 70 & 76 & 48 & 41 & 37 & 95 & 90 & 32 & 59 & 42 \\
\hline Feb. 4 & 35 & 47 & 37 & 16 & 0 & 39 & 65 & 26 & 16 & 9 \\
\hline
\end{tabular}

not strikingly different. No explanation for the different behavior in the two years is apparent.

The data in figure 9, upper graph, show an effect observed repeatedly in these temperature studies on garlic-the temperature level most effective in producing certain growth responses may shift with a change in the length of the storage period. For the two September planting dates, storage periods of three or six weeks at $5^{\circ}$ and $10^{\circ} \mathrm{C}$ resulted in more roughness than did storage at $0^{\circ} \mathrm{C}$. For the November (12 weeks of storage) and later plantings, the plants grown from bulbs stored at $0^{\circ} \mathrm{C}$ were as rough as or rougher than plants from bulbs stored at $5^{\circ}$ or $10^{\circ} \mathrm{C}$. The same type of response occurred with elongation of axillary shoots and time of maturity, and while not conspicuous, was almost always evident. The decrease in rest for roots and shoots showed a similar trend (Mann and Lewis, 1956), but shifted from $15^{\circ}$ or $10^{\circ} \mathrm{C}$ to $5^{\circ} \mathrm{C}$ (but not to $0^{\circ} \mathrm{C}$ ) with increasing length of storage. Stout (1946) has explained temperature-bolting relations in the sugar beet by hypothesizing two separate effects of temperature, one on degree of thermal induction and one on rate of thermally induced changes. The ultimate degree of thermal induction at low temperatures may be high, 

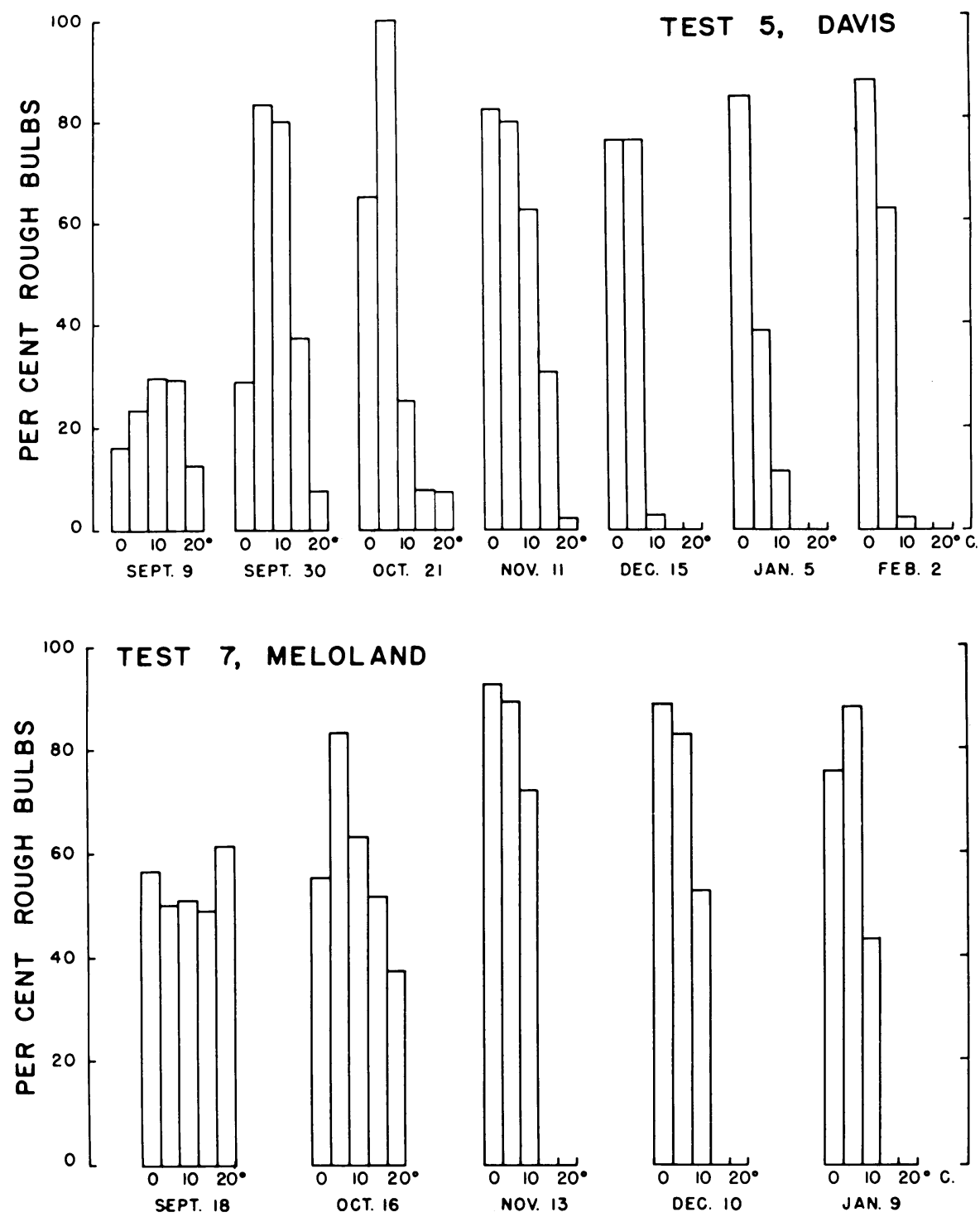

\section{STORAGE TEMPERATURE OF PLANTING}

STOCK AND PLANTING DATE

Fig. 9. Roughness of field-grown garlic as related to storage temperature of planting stock and planting date. Upper graph : bulbs grown at Davis from planting stock stored from August 19, 1952, until planting. Lower graph : bulbs grown at Meloland from planting stock stored from August 20, 1953, until planting. In test 7, bulbs stored at $20^{\circ} \mathrm{C}$ and planted November 13 did not form usable bulbs, nor did the $15^{\circ}$ or $20^{\circ} \mathrm{C}$ storage lots planted December 10 and January 9. 


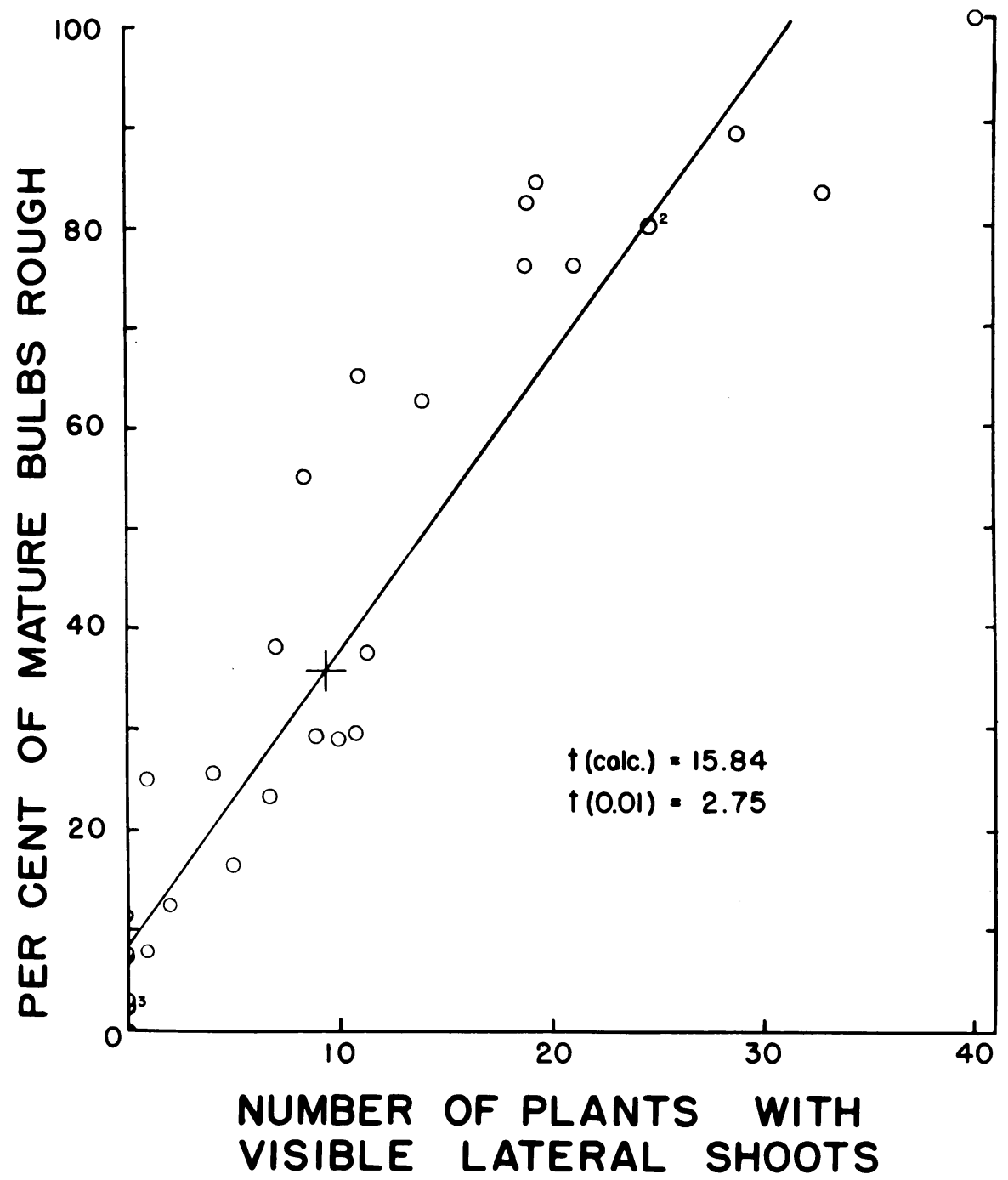

Fig. 10. Regression of per cent roughness of mature garlic bulbs on presence of visible lateral shoots in growing plants. Data from garlic planted on seven dates from bulbs stored at five temperatures. Each point is based on approximately 40 bulbs. (Test 5, Davis.) 
but the rate of induction is low, so that storage periods at low temperatures must be relatively long to produce marked induction effects. Most of the low-temperature responses in garlic appear to be reversed by high temperature, as is thermal induction in the sugar beet, and the relations noted above for garlic, between length of storage period and most effective storage temperature, could well be explained by Stout's hypothesis.

As in test 6 , there was a close association between per cent roughness of mature bulbs and the presence of visible lateral shoots in growing plants. Figure 10 shows a regression line of percentage of roughness of mature bulbs on number of plants with visible lateral shoots, for the data of test 5 .

TABLE 9

POSITION OF THE OUTERMOST VISIBLE LATERAL SHOOT IN GARLIC IN RELATION TO STORAGE TEMPERATURE OF PLANTING STOCK

(Test 6, Davis)

\begin{tabular}{|c|c|c|c|c|c|c|}
\hline \multirow{3}{*}{ Planting date } & \multirow{3}{*}{$\begin{array}{c}\text { Clonal } \\
\text { line no. }\end{array}$} & \multicolumn{5}{|c|}{ Position of outermost foliage leaf* with a visible axillary shoot } \\
\hline & & \multicolumn{5}{|c|}{ Storage temp. of planting stock $\left({ }^{\circ} \mathrm{C}\right)$} \\
\hline & & $0^{\circ}$ & $5^{\circ}$ & $10^{\circ}$ & $15^{\circ}$ & $20^{\circ}$ \\
\hline \multirow{5}{*}{ Dec. 9,1953 . } & $4-10$ & 5.2 & 6.1 & 7.0 & 8.7 & 8.0 \\
\hline & $7-1$ & 5.6 & 6.5 & $7.1(14) \dagger$ & & $8.4(7) \dagger$ \\
\hline & $7-4$ & 5.2 & 6.5 & $6.7(18) \dagger$ & $9.0(2) \dagger$ & $7.4(5) \dagger$ \\
\hline & $1-4$ & 5.5 & 6.2 & $7.2(17) \dagger$ & $8.0(9) \dagger$ & $8.0(7) \dagger$ \\
\hline & Mean & 5.4 & 6.3 & 7.0 & 8.5 & 8.0 \\
\hline
\end{tabular}

* Position refers to leaf number; leaves were numbered consecutively toward the bulb center, counting the outermost blade-bearing leaf as number 1 .

$\dagger$ Each figure is the mean of 20 plants except as shown by figures in parentheses.

Other tests. Figure 9, lower graph, shows roughness in relation to storage temperature and planting date for test 7 at the Meloland Station. As in test 5 , the response to storage temperature was marked; the lots from the $15^{\circ}$ and $20^{\circ} \mathrm{C}$ storage were unable to form bulbs when planted in midNovember or later.

While no data on roughness were recorded for test 8 at Tulelake, figure 4 (p. 399) shows that plants grown from bulbs stored at $0^{\circ}$ and $5^{\circ} \mathrm{C}$ were fairly rough. The $10^{\circ} \mathrm{C}$ lot was quite smooth, but higher storage temperatures essentially prevented bulb formation. This illustrates, as do the roughness data for the Meloland test, how narrow is the temperature requirement for production of smooth bulbs.

Tests 9 and 10, near San Juan Bautista and Gilroy, respectively, are of interest because they were conducted in a commercial garlic-growing area. Of the garlic put into storage in late August and planted in December, January, or early February, that from bulbs stored at $0^{\circ}$ and $5^{\circ} \mathrm{C}$ was rough, that from $10^{\circ} \mathrm{C}$ was rough to slightly rough, and that from $15^{\circ}$ and $20^{\circ} \mathrm{C}$ storage was smooth. The commercial garlic grown from bulbs held in common storage in this area is occasionally rough. Monthly mean temperatures for the area, as recorded at Hollister and San Jose, drop from around $19^{\circ} \mathrm{C}\left(66^{\circ} \mathrm{F}\right)$ in August to near $10^{\circ} \mathrm{C}\left(50^{\circ} \mathrm{F}\right)$ in December, $9^{\circ} \mathrm{C}$ 

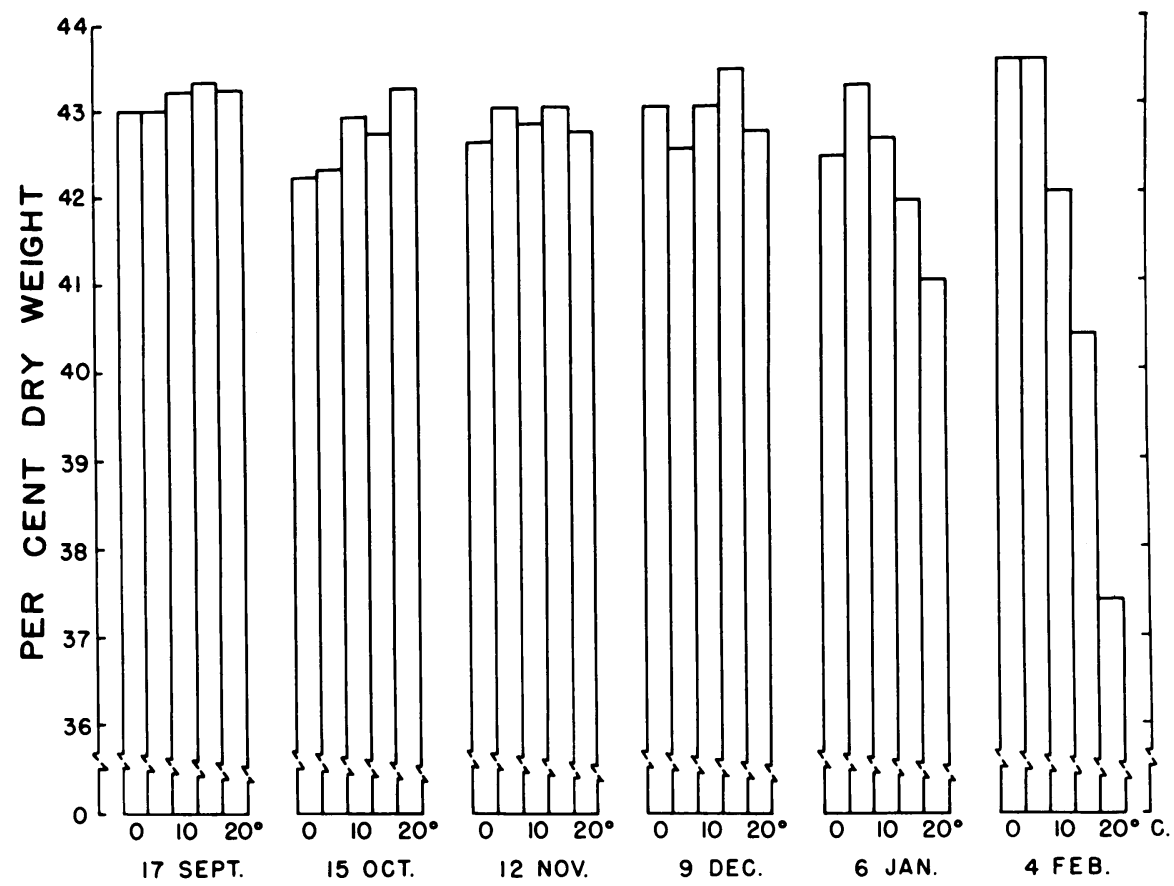

\section{STORAGE TEMPERATURE OF PLANTING STOCK AND PLANTING DATE}

Fig. 11. Dry-matter content of mature garlic bulbs as related to storage temperature of planting stock and planting date. Bulbs grown from planting stock stored at five temperatures from August 20, 1953, until planting. Each bar is the mean value from determinations made on each of four clonal lines. (Test 6, Davis.)

$\left(48^{\circ} \mathrm{F}\right)$ in January, and $10^{\circ} \mathrm{C}\left(50^{\circ} \mathrm{F}\right)$ in February. Assuming that temperatures of common storage are near these mean temperatures, it follows that the temperature for most of the storage period is above a level which, if used continuously between harvest and planting date, would produce rough garlic. Nonetheless, storage and field temperatures are sufficiently low that the occasional production of rough garlic occurs.

\section{DRY-MATTER CONTENT OF BULBS}

Test 6. A total of 240 dry-weight determinations was made on the mature bulbs of test 6 (duplicate samples $\mathrm{x} 4$ clonal lines $\mathrm{x} 5$ storage temperatures $\mathrm{x} 6$ planting dates). For each determination, the cloves from 25 bulbs were separated, mixed, and the loose scales were removed by blowing with air. The entire sample was ground in a Hobart food grinder for 25 seconds, and duplicate 200-gm samples were placed on cheesecloth in stainless steel baskets and dried in a force-draft dehydrator at $52^{\circ} \mathrm{C}$ for 24 hours or more. Dry weight as per cent of fresh weight is shown in figure 11. Each bar is the mean of four clonal lines.

Dry matter was near 43 per cent, usually not varying from this value 

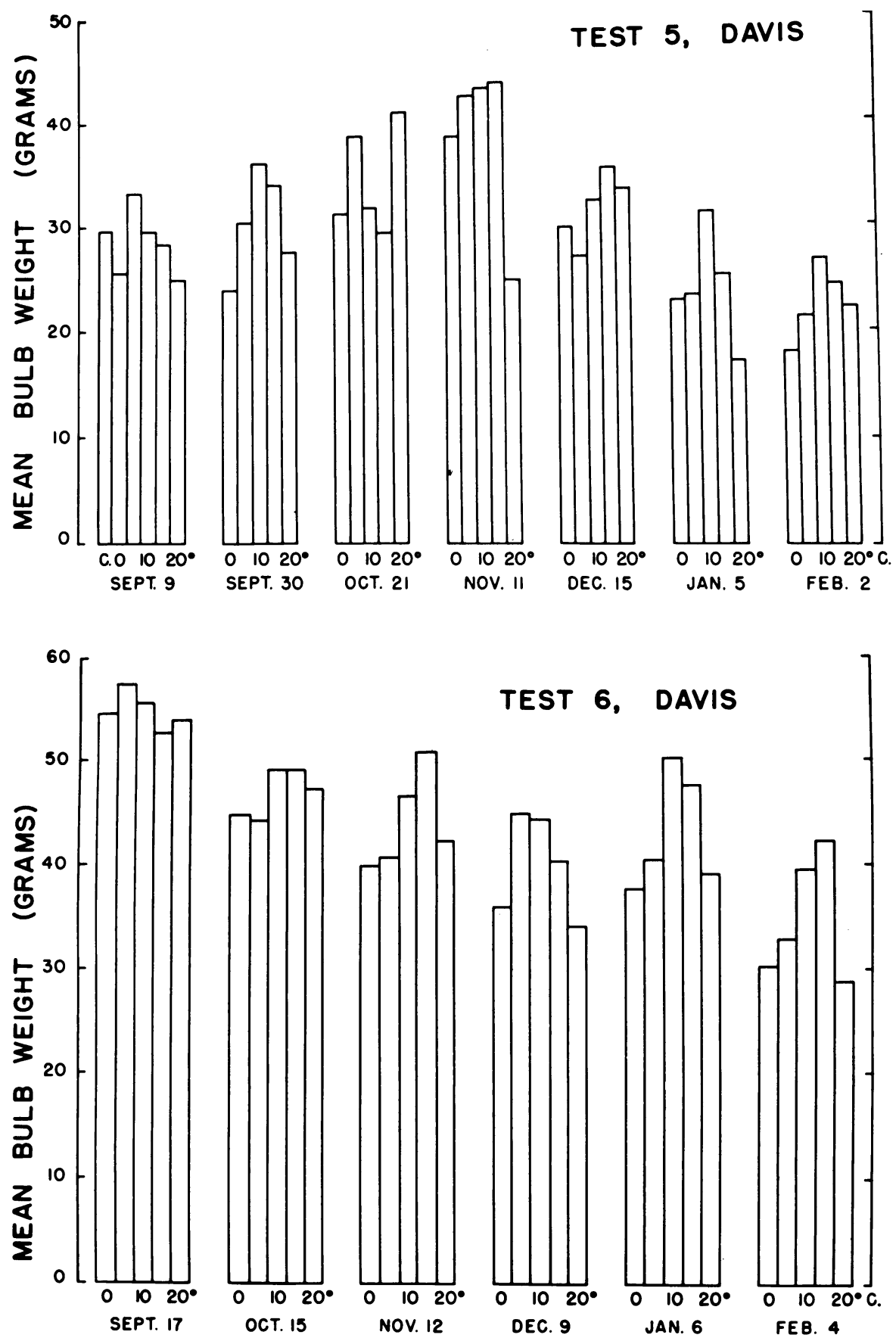

\section{STORAGE TEMPERATURE OF PLANTING STOCK AND PLANTING DATE}

Fig. 12. Weight of mature garlic bulbs as related to storage temperature of planting stock and planting date. Upper graph: bulbs grown at Davis from planting stock stored from August 19, 1952, until planting. Lower graph: bulbs grown at Davis from planting stock stored from August 20, 1953, until planting. 

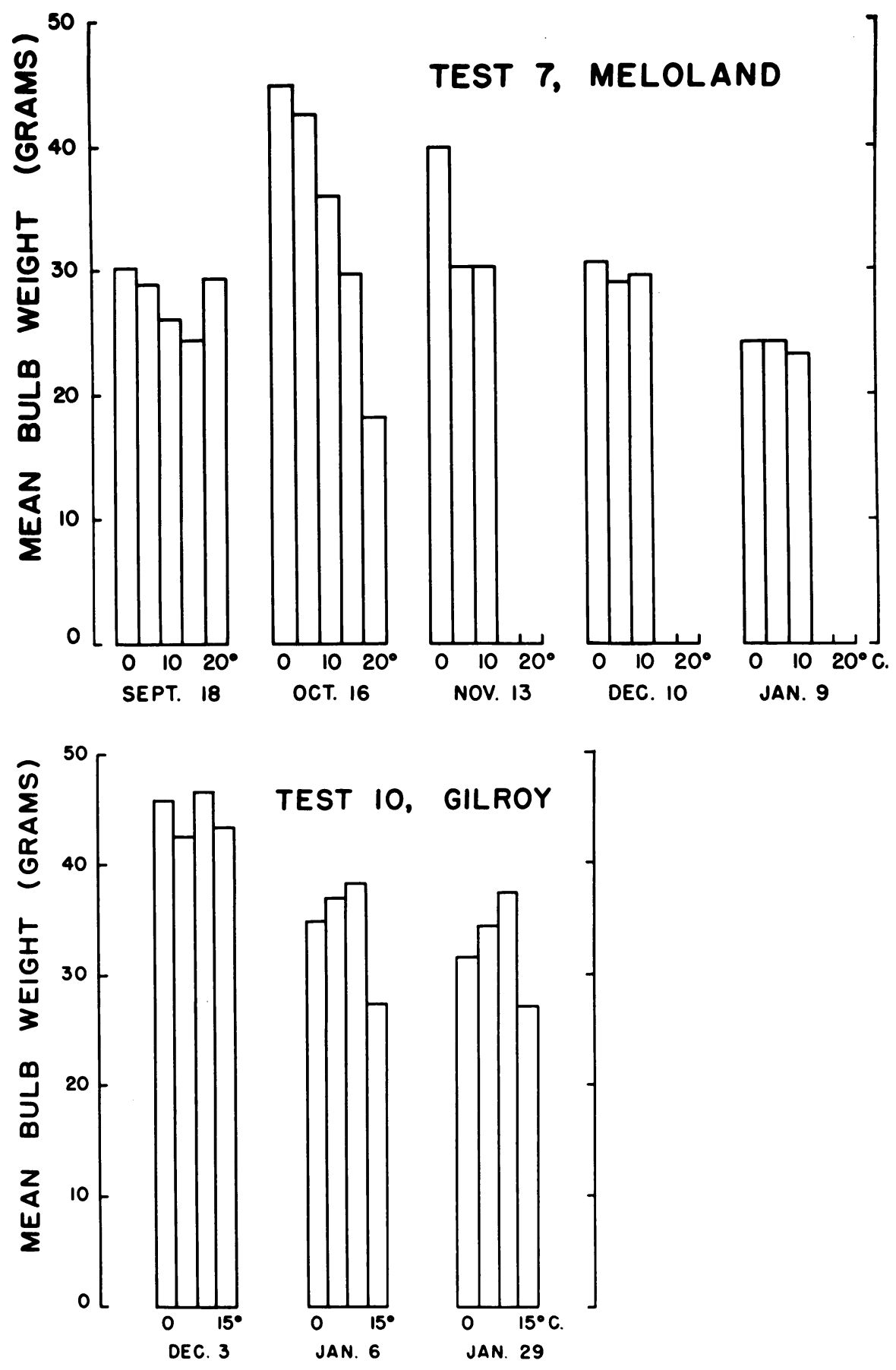

\section{STORAGE TEMPERATURE OF PLANTING STOCK AND PLANTING DATE}

Fig. 13. Weight of mature garlic bulbs as related to storage temperature of planting stock and planting date. Upper graph: bulbs grown at Meloland from planting stock stored from August 20,1953, until planting. Lower graph: bulbs grown near Gilroy from planting stock stored from August 20, 1953, until planting. 
over one half of a per cent unit except for the late plantings from bulbs held at the higher storage temperatures (January plantings from the $15^{\circ}$ and $20^{\circ} \mathrm{C}$ storages and February plantings from the $10^{\circ}, 15^{\circ}$, and $20^{\circ} \mathrm{C}$ storages). These later plantings received little exposure to low temperature, either in storage or in the field, and matured rather slowly (see fig. 6, p. 405). These data indicate that dry-matter content of bulbs grown in one area is not significantly affected by variations in planting date or in storage temperature of planting stock, except that it is low in plants receiving so little exposure to low temperature that maturity is delayed.

\section{BULB WEIGHT}

The tests set up in the present series of experiments were designed for observations on growth responses and were not randomized for analysis of yield data. However, bulb weights were determined in several tests, and some general comments can be made on these. Bulb weights cannot be compared directly with yields, i.e., production per unit area.

Tests 5 and 6 at Davis (fig. 12), test 8 at Tulelake, and test 10 near Gilroy (fig. 13) all indicated that larger bulbs were produced from planting stocks held at $10^{\circ}$ or $15^{\circ} \mathrm{C}$ than at $0^{\circ}$ or $5^{\circ} \mathrm{C}$. The September plantings of tests 5,6 , and 7 are not included in this comparison since one month of storage appears to have had little effect on plant growth. Only in test 7 (fig. 13), in the warm Meloland area, did cloves from storage stock held at $0^{\circ}$ and $5^{\circ} \mathrm{C}$ produce bulbs as large as or larger than those from higher temperatures. It will be recalled that at this station, plants grown from planting stock at $15^{\circ}$ and $20^{\circ} \mathrm{C}$ failed to form bulbs if planted in mid-November or later. In the Gilroy area (test 10 ), bulbs from stock stored at $15^{\circ} \mathrm{C}$ were smaller than those from $10^{\circ} \mathrm{C}$ storage, and in all tests cloves from $20^{\circ} \mathrm{C}$ storage generally produced smaller bulbs than did cloves from $10^{\circ}$ or $5^{\circ} \mathrm{C}$. All the above comparisons are within planting dates, i.e., among units planted on the same date but drawn from planting stocks held at different temperatures.

When bulb sizes are compared among planting dates, test 6 at Davis (except for the January plantings) showed that bulb weight generally decreased with each delay in planting. In tests 5 (Davis) and 7 (Meloland), the September plantings yielded smaller bulbs than the October or November plantings, and bulb size decreased with later plantings. For the spring plantings at Tulelake (test 8), the April 1 plantings produced larger bulbs than those of April 29, a not unexpected result considering the short growing period. The plantings of April 29 from $0^{\circ}$ and $5^{\circ} \mathrm{C}$ storage matured in about four months; a seven-month period is common in commercial areas.

\section{SUMMARY AND DISCUSSION}

The response of California Late garlic to temperature and photoperiod may be briefly summarized as follows. When garlic reaches maturity in the field, the cloves are in rest and neither sprout nor root readily. Rest decreases gradually in storage-most rapidly at $5^{\circ}$ or $10^{\circ} \mathrm{C}$, and less rapidly at higher and lower temperatures. This decrease continues over a period of four to five months or more. If bulbs have been stored at controlled tempera- 
tures, cloves from $5^{\circ}$ or $10^{\circ} \mathrm{C}$ sprout most quickly and vigorously, those from $0^{\circ}$ or $20^{\circ}$ least quickly. After sprouting, the vigor of growth, as measured by plant height, is greatest in plants from cloves stored at $0^{\circ} \mathrm{C}$, least in plants from cloves exposed to $20^{\circ} \mathrm{C}$. Plants from cloves exposed to $0^{\circ}$ or $20^{\circ} \mathrm{C}$ have narrow leaves and thin false stems, those exposed to intermediate temperatures, e.g., $10^{\circ} \mathrm{C}$, have thick stems and broad leaves. Bulbs form in response to the long days of spring and early summer, but this response is strongly influenced by the temperature to which the dormant cloves or growing plants have been exposed. For storage periods of one or two months, bulbs form most quickly in plants exposed to $0^{\circ}$ or $5^{\circ} \mathrm{C}$, and for longer periods of exposure, from plants held at $0^{\circ} \mathrm{C}$. Plants never exposed to temperatures below $20^{\circ} \mathrm{C}$ may fail to form bulbs, even under long days. Plants growing under long days, and which have previously had adequate exposure to low temperature, form and mature bulbs most quickly under warm temperatures. Time of maturity, as in most plants sensitive to day length, tends to be uniform even from widely spaced planting dates. However, maturity, like bulb formation, may be delayed if plants have received little exposure to low temperature. Plants exposed for long periods to low temperatures may initiate cloves in the axils of leaves near the bulb surface, i.e., farther from the bulb center than is usual. During the growing season these cloves develop green tops which appear as lateral shoots to the main false stem, and as the plants mature, the loss of a few outer sheaths exposes the outermost cloves so that the bulbs appear rough. Most of the temperature responses of garlic seem to be reversible, i.e., the effects of exposure to one temperature may be reversed or modified by subsequent exposure to another temperature. This reversibility must be considered in evaluating responses in field plantings where temperatures are continually shifting. For garlic stored at controlled temperatures and then planted in the field, the plants show little response to storage periods of less than one month. Variations in storage temperature of planting stock or in planting date appear to have little effect on the dry-matter content of mature bulbs unless conditions are such that maturity is delayed, in which case bulbs have a low solids content. Storage temperature of planting stock and planting date may have a marked effect on the weight of mature bulbs, depending in part on the field temperatures and day lengths following planting.

It seems doubtful that controlled-temperature storage will be of use in the commercial garlic areas of California. Garlic is imported into the United States from many parts of the world, and California farmers have for years been growing test plots of kinds unfamiliar to them. Through this process they have selected those kinds well-adapted to local farming methods. Common storage is more economical than controlled-temperature storage, and the kinds now grown have been selected to fit the common storage temperatures of the commercial areas. Cold storage of planting stocks has been tried occasionally by farmers. Following such storage, emergence may be much more rapid and uniform than in stock from common storage. This has cultural advantages - for example in weed control-and may aid in avoiding Penicillium decay, a serious disorder in some commercial areas (Mann and Little, 1957). Early growth is also vigorous, but garlic receiving much more 
exposure to low temperature than is received in common storage is usually rough.

On the other hand, a knowledge of the responses of garlic to temperature and day length is essential for understanding growth responses in unusual seasons, and in selecting planting dates, storage conditions, or cultivars (cultivated varieties) for areas where garlic has not previously been grown.

The responses of garlic to temperature and photoperiod summarized above will undoubtedly be modified as additional data become available, and several points on which information is lacking or limited should be emphasized.

Except for a few experiments on California Early garlic (Mann, 1952), all observations have been made on one cultivar only, California Late garlic. It is known that garlic adapted to one area may be completely worthless as a commercial crop in other areas. Comin (1942), growing garlic in Ohio, found that local home garden garlic did well but that California material did not. California Late garlic is not well suited to the Imperial Valley, and, at Davis, a number of collections from Mexico do not form bulbs of usable size. Garlic is known to grow well in central Peru where, compared with California, day lengths are relatively short and temperatures never low. The rest period also differs markedly among cultivars; that of California Early garlic is much shorter than that of California Late, so much so that the Early garlic is seldom held in storage. These obvious variations among cultivars undoubtedly involve large differences in response both to temperature and photoperiod. It would be of value to know the critical day lengths for bulbing of several early and late types of garlic. These day lengths would probably vary with the temperature and length of the storage period of bulbs before planting. Such information is not now available for the California Late garlic or for other types.

In onion, cabbage, and many other plants sensitive to temperature (with respect to bolting), a plant must be of a certain minimum size to respond to temperature. Whether temperature sensitivity in garlic varies with clove size is not known. Garlic is not grown from true seed, and all cloves experimented with have been of fairly uniform size, although the data on rest (Mann and Lewis, 1956, p. 179) indicate that size of clove has no great effect.

The sensitivity of garlic cloves to temperature during maturation is as yet unknown. If they are responsive, then two lots of genetically uniform garlic, if derived from areas where the parent plants matured at different temperatures, might show distinct growth patterns. This type of behavior has been observed with naturally vernalized seed (Whyte, 1948).

In all of the storage and planting date experiments reported here, there was little bolting, and when bolting was observed it showed no evident correlation with the treatments applied. The amount of bolting in garlic varies markedly among cultivars and is seldom observed in California Late garlic. While bolting appears to be more common in some areas than in others, indicating that climate may be involved, the factors controlling bolting are unknown. 


\section{ACKNOWLEDGMENTS}

Mr. Grant Baughn and Mr. Orval McCoy, Assistant Specialists in Vegetable Crops, University of California, conducted the tests at the Meloland Station, Imperial County. Mr. William Seyman, Farm Advisor, Santa Clara County, and Mr. Frank Zink, Associate Specialist in Vegetable Crops, conducted the tests near San Juan Bautista and Gilroy. Mr. Burton J. Hoyle, Superintendent of the Field Station, conducted the test at Tulelake. These individuals assumed full supervision of those tests; the work could not have been done without their help. Miss Dora G. Hunt, Senior Laboratory Technician, and David A. Lewis, Fulbright Fellow, both at the University of California, Davis, assisted at all stages of the work at Davis. Dr. T. M. Little, Extension Specialist in Vegetable Crops, University of California, Riverside, and Dr. H. A. Jones, Dessert Seed Co., El Centro, California, kindly read the manuscript. We are most grateful for their help.

\section{LITERATURE CITED}

Comin, Donald

1942. Growing garlic in the north. Ohio Agr. Exp. Sta. Bimonthly Bul. 27(215) : 70-71. ManN, Louis $\mathrm{K}$.

1952. Anatomy of the garlic bulb and factors affecting bulb development. Hilgardia 21(8):195-251.

ManN, Louis K., and David A. LEWIS

1956. Rest and dormancy in garlic. Hilgardia 26(3):161-89.

MANN, L. K., and T. M. LiTTLE

1957. Growing garlic in California. Univ. of Calif. Veg. Crops Series No. 89. Davis, California.

SNedecor, GeORGE W.

1946. Statistical methods. Iowa State College Press, Ames, Iowa.

STOUT, MYRoN

1946. Relation of temperature to reproduction in sugar beets. Jour. Agr. Res. $72(2): 49$ 68.

Whyте, R. O.

1948. History of research in vernalization. Vernalization and photoperiodism, pp. 1-38. Chronica Botanica Co., Waltham, Mass. 

The journal Hilgardia is published at irregular intervals, in volumes of about 600 pages. The number of issues per volume varies.

Subscriptions are not sold. The periodical is sent as published only to libraries, or to institutions in foreign countries having publications to offer in cxchange.

You may obtain a single copy of any issue free, as long as the supply lasts; please request by volume and issue number from:

Agricultural Publications

Room 22, Giannini Hall

University of California

Berkeley 4, California

The limit to nonresidents of California is 10 separate issues on a single order. A list of the issues still available will be sent on request. 


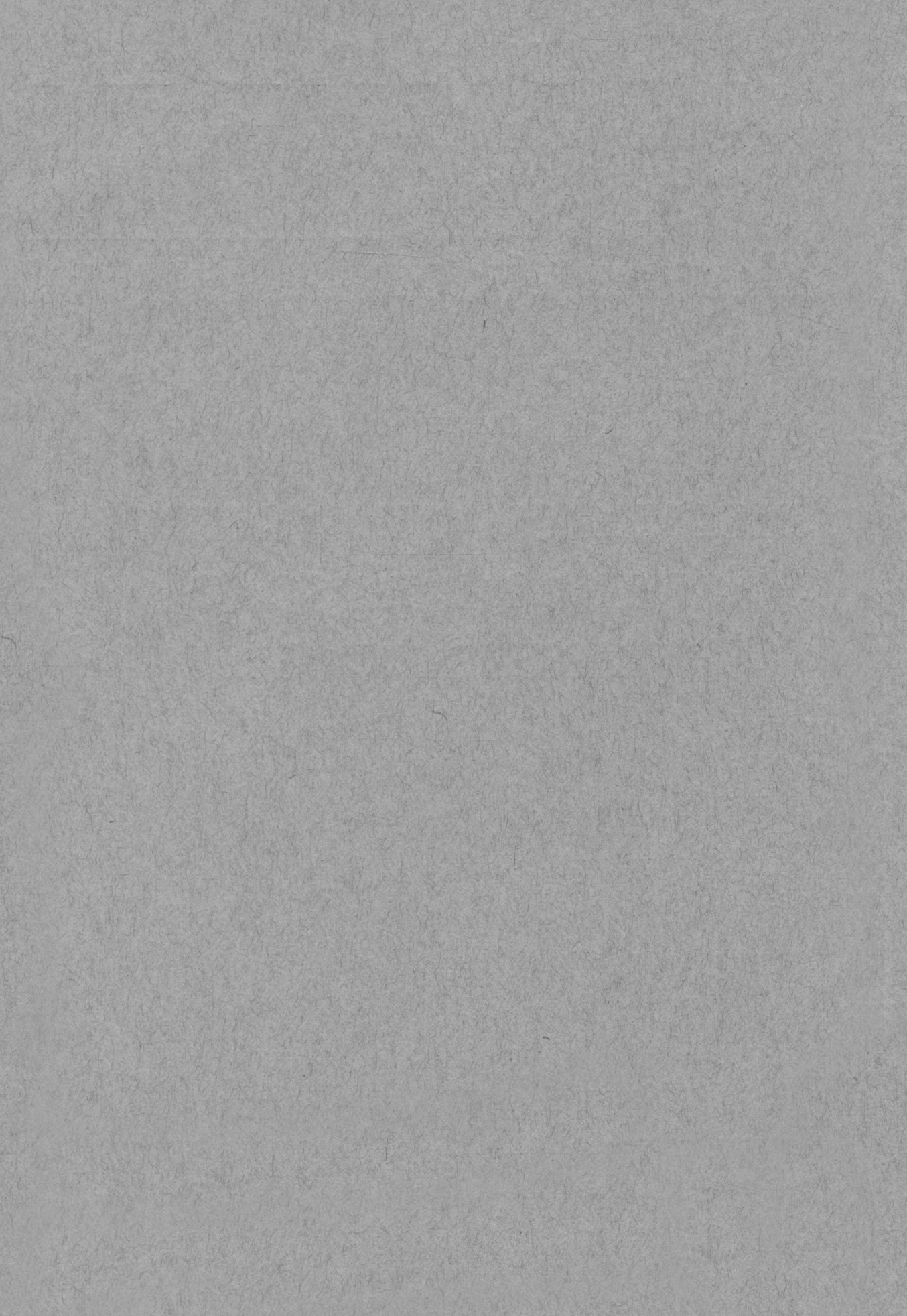

